\title{
The auriferous ore mineralisation and its zonal distribution around the Variscan Kłodzko-Złoty Stok granitoid pluton in the Sudetes (SW Poland) - an overview
}

\author{
Stanisław Z. MIKULSKI ${ }^{1, *}$ and Stanisław SPECZIK ${ }^{1}$
}

1 Polish Geological Institute - National Research Institute, Rakowiecka 4, 00-975 Warszawa, Poland

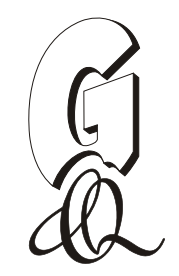

Mikulski, S.Z., Speczik, S., 2016. The auriferous ore mineralisation and its zonal distribution around the Variscan Kłodzko-Złoty Stok granitoid pluton in the Sudetes (SW Poland) - an overview. Geological Quarterly, 60 (3): 650-674, doi: 10.7306/gq.1284

Due to a low level of erosion the Variscan (Carboniferous-Mississippian) Kłodzko-Złoty Stok (KZS) granitoid pluton and its metamorphic rock cover are unique examples of the ore mineralisation distribution pattern around a pluton. The KZS pluton formed from l-type magmas. It is composed mostly of high-K, metaluminous, biotite- and hornblende-rich granitoids of various compositions ranging from granodiorite to monzonite. The ore mineralisation in the KZS shows specific zonation that reflects interaction between post-magmatic mineralising fluids and country rocks of different composition. In the KZS pluton and its surroundings the mineralisation reveals high-temperature Ti-W oxides and As-Fe sulphide-arsenides plus Fe-oxides which are replaced outwards by $\mathrm{Cu}-\mathrm{Fe}-\mathrm{Pb}-\mathrm{Zn}$ sulphides and subsequently, in the marginal parts of the pluton, by the $\mathrm{Pb}-\mathrm{Sb}$-Fe sulphide mineralisation. The specific elements and the isotopic composition of sulphur in ore minerals indicate that the metal-bearing postmagmatic-metamorphic hydrothermal fluids, despite their strong affinities to the KZS hybrid magmatic fluids, show also an influence of variable composition of country rocks. Variable alteration processes: hornfelsitisation, skarnisation, dolomitisation, serpentinitisation, pyroxenisation, biotitisation, K-feldspatisation, silicification, berezitisation, carbonatisation, prehinitisation, chloritisation, epidotisation, sericitisation, albitisation and sulphidisation developed along contacts of various rock types within the country rocks. In more fractured zones, transported elements were preferentially trapped by calcareous (Ca-rich) metamorphic rocks. Moreover, along the direct contact between granitoids and calcareous rocks a high temperature auriferous skarns with magnetite-pyrrhotite or/and löllingite-arsenopyrite mineralisation were formed. There are positive correlations between organic matter and $\mathrm{Fe}_{2} \mathrm{O}_{3}$ and $\mathrm{MgO}$ contents in skarns, suggesting remobilization of organic matter by hydrothermal fluids released during serpentinisation. The organic matter and carbonate samples have very variable $\delta^{13} \mathrm{C}$ and $\delta^{18} \mathrm{O}$ values. Most probably these are the result of isotopic re-equilibration between minerals under high temperatures. On the intimate contact of granitoids with less permeable amphibolitic hornfelses a high temperature titanite-scheelite mineralisation of veinlet-impregnation type occurred, while thermal and metasomatic alteration of the enveloping more permeable sandstones developed away from direct contact with granites, causing the formation of pyrite-rich beresites. As a rule, different types of sulphide ore mineralisation contain refractory gold captured by arsenopyrite, löllingite and/or pyrite. Moreover, the formation of contact-metasomatic ore mineralisation was accompanied by ore precipitation in veins and stockworks at a wide temperature range from 480 to $150^{\circ} \mathrm{C}$ during early and late fracturing stages. The younger stages also revealed variable concentration of gold. All those observations strongly indicate that the whole KZS pluton and its aureole was fertile in gold.

Key words: gold, ore mineralisation, skarn, Variscan granitoids, Kłodzko-Złoty Stok pluton, Sudetes.

\section{INTRODUCTION}

The paper focuses on mineralogical and geochemical characterization of the auriferous ore mineralisation which reflects specific zonal distribution relative to the core of the Variscan Kłodzko-Złoty Stok granitoid pluton (KZS) and its metamorphic aureole. The study area is located in the NE part of the Bohemian Massif in the Sudetes, Central Europe. The first written re-

\footnotetext{
* Corresponding author, e-mail: stanislaw.mikulski@pgi.gov.pl
}

Received: October 5, 2015; accepted: February 3, 2016; first published online: March 21, 2016 cord about the famous gold mines near Reichenstein (German name; Polish name - Złoty Stok) in the intimate vicinity of the KZS pluton is dated back to 1341 (Dziekoński, 1972). Gold production was the only type of exploration that took place until the end of the 17th century. In 1701, the world's first arsenic smelter was built and production of arsenic concentrate started (Wiencke, 1907). The total gold production from the Złoty Stok deposit (14-20th centuries) is roughly estimated for at least $15 \mathrm{t}$ and that of the arsenic trioxide at around 130,000 t. The genesis of the Złoty Stok Au-As deposit was commonly linked with KZS pluton and the ore deposits were classified as of the contact-metasomatic or the skarn-type deposits (e.g., Kowalski, 1963, 1969; Budzyńska, 1971; Mikulski, 1996, 2011, 2015; Muszer, 1997, 2011). However, the pre-Variscan metamorphosed ore mineralisation was also recognized within the metamorphic aureole of the KZS pluton (Muszer, 1997). 
The European Variscan orogenic gold deposits formed at ca. 350-280 Ma in uplifting massifs along the active western edge of the Palaeo-Tethys Ocean (Goldfarb et al., 2000; Groves et al., 1998a, b, 2005). Those deposits are now exposed mainly in the Southern and Central Europe. Processes of gold mineralisation recognized in the Sudetes are quite similar to gold-mineralisation processes described from the other areas of the European Variscan Belt. However, the age of the gold ore formation is variable. The similar features include geotectonic evolution, two- or three-stage evolution of fluid compositions and mineral precipitation, characteristic mineral parageneses and textures (e.g., Morávek et al., 1996; Zachariáš et al., 2013, 2014; Noronha et al., 2000; Cathelineau et al., 2003). Gold formation, exhumation of host rocks, extensional tectonic setting and intrusion of lamprophyre dykes appear coeval in the Massif Central, Central Bohemian Province (Bouchot et al., 1989, 2000, 2003) and in the KZS pluton as well (Mikulski et al., 2013). In the Polish part of the Bohemian Massif four main stages of gold formation (Au1 to Au4) during Carboniferous-Permian times have been recognized (Mikulski, 2007a, b). In the KZS the earliest stage (Au1) associated with the emplacement of syn-collisional granites (Visean) has been identified. The next stages (Au2 and Au3) were connected with geodynamic transition from post-collisional to within-plate setting. These stages imply a change from mesothermal to epithermal conditions of gold precipitation during post-magmatic and volcanic processes related to orogenic uplift and deep fracturing (Upper Namurian-Stephanian-Autunian). The youngest stage (Au4) was the result of low-temperature hydrothermal processes during the Late Permian and/or Triassic basin evolution. Some gold deposits from the other parts of the Sudetes were classified by Mikulski (2007a) as orogenic-type (Klecza-Radomice Au deposit) according to the classification of Groves et al. (1998a, b, 2005; Goldfarb et al., 2000), and other Au deposits as transitional from the porphyry- to epithermal-type (Radzimowice Au,Cu deposit; Mikulski, 2005a). According to the models proposed by Thompson et al. (1999), Lang et al. (2000), and Lang and Baker (2000) some of the ore manifestations found in the KZS pluton and in its metamorphic aureole can be classified as intrusion-related gold deposit type. Moreover, calc-alkaline and alkaline magmas were considered as a possible source of gold in numerous gold deposits (Richards, 1995; Spiridonov, 1996; Sillitoe, 1991, 2000; Sillitoe and Thompson, 1998; Thompson and Newberry, 2000; Jensen and Barton, 2000; Müller and Groves, 2000). The geotectonic setting of different $\mathrm{Cu}-\mathrm{Au}$ and Mo-Cu mineralisations and gold deposits related to alkaline magmatism are traditionally explored in arc-zone accreted terranes and in areas of extensional tectonics (Sillitoe, 2000; Jensen and Barton, 2000; Müller and Groves, 2000). On the multi-component discrimination diagram R1 vs. R2 (Batchelor and Bowden, 1985), most of the KZS granitoids are located within the pre-plate-collision group. The remainder of the KZS granitoids is transitional to the post-collision uplift group (Mikulski et al., 2013).

Modern models of the gold deposits classification (e.g., Jensen and Barton, 2000; Müller and Groves, 2000) does not strongly indicate significant zonal distributions of deposits in relation to the source acidic (granitic) magmas. Beside the KZS in the Sudetes the zonal distribution of ore deposits was also recognized around the Variscan Karkonosze Massif (Petrascheck, 1933; Neuhaus, 1933; Mochnacka, 2000; Mikulski, 2010). In this paper we would like to present new data and summarize our previous results to demonstrate a model of such specific distribution of the ores in the KZS pluton and its metamorphic aureole.

\section{GEOLOGICAL SETTING \\ OF THE KŁODZKO-ZŁOTY STOK GRANITOID PLUTON AND ITS SURROUNDINGS}

The Kłodzko-Złoty Stok granitoid pluton (KZS) is located in the Sudetes Block that constitutes the northeastern part of the Saxothuringian Zone of the European Variscan Belt (Fig. 1). The basement of the Sudetes is built of Neoproterozoic and Paleozoic rocks affected by Cadomian and Variscan metamorphism (Franke and Żelaźniewicz, 2000). In the Sudetes, several large granitic plutons, including the KZS, were emplaced in the Carboniferous (e.g., Mazur et al., 2007, and references therein). The upper limit of the Variscan tectonometamorphic and magmatic activity was dated at 314-312 Ma (Namurian/Westphalian boundary) by ${ }^{40} \mathrm{Ar} /{ }^{39} \mathrm{Ar}$ method (Marheine et al., 2002) and by SHRIMP method for younger Permian ages (Awdankiewicz et al., 2014; Mikulski and Williams, 2014b; Oberc-Dziedzic et al., 2015). The granitoids intruded between different tectonostratigraphic units which have been interpreted as terrane assemblages (Matte et al., 1990). The Variscan geological structures are overlain by the Permian, Triassic, Cretaceous and Cenozoic platform sedimentary cover (Oberc, 1972).

The KZS is bordered on the NW by the Bardo Unit, on the $E$ and $S$ by the Śnieżnik Massif, and on the SW by the Kłodzko Unit. The KZS pluton crops out over an area of $120 \mathrm{~km}^{2}$ and represents a depression between the Bardo Mts. on the NW and the Góry Złote and Krowiarki Range on the SE and S. The KZS pluton emplacement was influenced to various degrees by older tectonic-lithological structures in the Cambrian to Mississippian sedimentary and metamorphic rocks (Wojciechowska, 1975). To the north the KZS pluton is separated from the Fore-Sudetic Block by a major dislocation, the Marginal Sudetic Fault Zone. The main deformation in the KZS pluton surroundings occurred during the Middle to Late Devonian, to be soon followed by a regional uplift and a succession of overprinting Carboniferous tectonic pulses (Mazur et al., 2006). The collision of the Central Sudetes orogenic wedge with the Bruno-Vistulian terrane commenced during the earliest Mississippian and lasted until the turn of the Mississippian and Pennsylvanian (Schulmann and Gayer, 2000; Jastrzębski, 2009; Chopin et al., 2012; Mazur et al., 2015). The KZS was emplaced at ca. 344-330 Ma (Mikulski et al., 2013). The roof of KZS is composed of irregularly distributed relics of Lower Paleozoic metamorphic rocks corresponding to the Orlica-Śnieżnik Dome. These rocks comprise sedimentary rocks with intercalations of mafic and felsic volcanites regionally metamorphosed in the amphibolite facies and then affected by contact metamorphism of the KZS intrusion. They are now represented mainly by hornfelses and amphibolites, which may suggest a shallow erosion level of the intrusion. In detail, the contact-metasomatic aureole of the KZS pluton consists of garnet-cordierite hornfelses, hercynite-corundum hornfelses, skarns, skarnoids, marbles, reaction granitoids and various pyroxene-plagioclase rocks (Wierzchołowski, 1976). The thermal and metasomatic influence of the KZS pluton is especially well-pronounced on its contacts with the rocks of the Kłodzko Metamorphic Unit and with the Bardo Unit. The SE and NE borders with the rocks of the Lądek-Śnieżnik Metamorphic Unit are influenced mostly by thermal and to a lesser degree by metasomatic activity. Along the Marginal Sudetic Fault, up to a $70 \mathrm{~m}$ zone of cataclastic breccias is recognized (Cwojdziński, 1974). Along the eastern limits of the KZS pluton the regional Złoty Stok-Skrzynka 


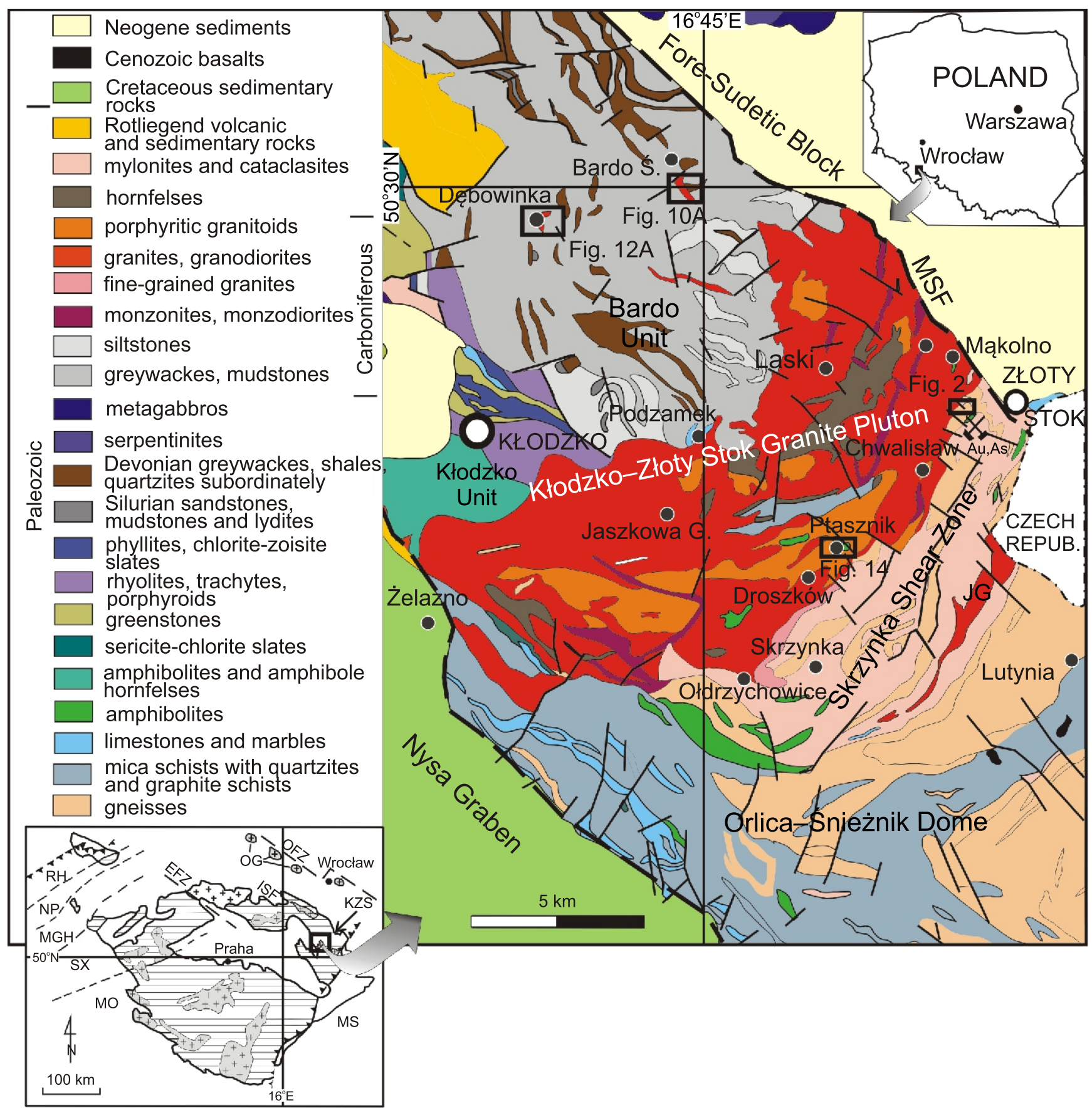

Fig. 1. Geological map of the Kłodzko-Złoty Stok Granite Pluon environs (acc. to Sawicki, 1980) with the sketch of the Bohemian Massif in the lower left

EFZ - Upper Elbe Fault Zone; ISF - Intra-Sudetic Fault; JG - Jawornik granitoids; KZS - Kłodzko-Złoty Stok Granite Pluton; MGH Mid-German Crystalline High; MO - Moldanubian Zone; MS - Moravo-Silesian Zone; MSF - Marginal Sudetic Fault; NP - Northern Phyllite Zone; OFZ - Middle Odra Fault Zone; OG - Odra granitoids; RH - Rhenohercynian Zone; SX - Saxothuringian Zone; black rectangles in the main map show location of the more detailed figures

Shear Zone, up to $4 \mathrm{~km}$ wide, developed during Variscan deformation (Cymerman, 1996). Metasomatic processes are best developed on the E and SE borders of the KZS pluton on contacts with metamorphic rocks of the Złoty Stok-Skrzynka Shear Zone that deforms the Stronie Series rocks.

The magmatic suite of the KZS pluton is composed of metaluminous calc-alkaline igneous rocks rich in biotite and hornblende, with rare xenoliths of metamorphic rocks and nu- merous mafic enclaves (Wierzchołowski, 1976). The Kłodzko-Złoty Stok pluton is a syn-collisional I-type intrusion (Mikulski et al., 2013). It contains, however, an extraordinary range of lithologies, with often rapid transitions between granodiorite (the main type), monzodiorite, quartz monzonite, tonalite, monzodiorite, syenite and diorite. Small ultrabasic and gabbroic bodies of uncertain form are found throughout the intrusion. Dyke rocks, especially porphyritic microgranodiorites 
and other fine-grained types of granitoids, syenitoids and dioritoids, are very similar in their chemical and mineral composition and petrography to the granitoids of the KZS pluton (Wierzchołowski, 1977; Bachliński and Bagiński, 2007). Pegmatites, aplites and quartz veins represent leucocratic differentiation products of the granodioritic magma. Lamprophyric dykes (spessartite, vogesite) occur commonly in the KZS pluton. The lamprophyre magmas were probably one of the main mafic components that mixed with felsic magmas within the KZS pluton (Lorenc, 1994; Bagiński et al., 2014). The hornblende-dominated fractional crystallisation of wet magmas led to spessartitic compositions, while plagioclase-dominated fractional crystallisation from volatile-depleted magma batches resulted in the formation of monzodioritic magmas (Awdankiewicz, 2007). A SHRIMP zircon age of ca. 333 Ma was reported from spessartite dyke in the Mąkolno Quarry (Mikulski et al., 2013).

\section{MATERIAL AND METHODS}

More than 200 rock samples with ore mineralisation were collected for gold investigation from the whole area of the Kłodzo-Złoty Stok granitoid pluton. Most of the results are presented for the Złoty Stok deposit and the Bardo Śląskie, Ptasznik and Dębowinka prospects (see Fig. 1 and Appendices*1-12). Gold contents were analysed at the Chemical Laboratory of the Polish Geological Institute - National Research Institute (PGI-NRI). Rock samples, after calcination at the temperature range of $450-640^{\circ} \mathrm{C}$, were digested with aqua regia. The resulted gold-bearing chloride complex was extracted to the MIBK (methyl isobutyl ketone) form. The MIBK fraction was analysed by the Graphite Furnace Atomic Absorption method (GF-AAS) using a Perkin Elmer model 4100 ZL spectrometer. Using this technique, gold contents were measured with a detection limit of $1 \mathrm{ppb}$.

Major elements and trace metals were measured at the PGI-NRI laboratory by wave-length dispersive X-ray fluorescence and/or by digestion-Inductively Coupled Plasma (ICP-AES) techniques. Major elements were measured on glass beads, and minor and trace elements on powder pellets using a $P W-2400$ Philips WD-XRF system. Measurement conditions were as follows: radiation - X-ray tube with rhodium anode ( $3 \mathrm{~kW}$ ); crystals - LiF 200, PE, Ge, PX1; collimators: $0.15 \mathrm{~mm}, 0.30 \mathrm{~mm}$; detectors: scintillation counter, flow proportional counter $(\mathrm{Ar} / \mathrm{CH} 4)$ and Xe-sealed proportional counter. Total uncertainty of the whole procedure applied during the XRF analyses was estimated to be $\pm 5 \%$ for major oxides and $\pm 8 \%$ for trace elements.

Detailed microscopic studies in reflected light were carried out on the NIKON ECLIPSE LV100 POL type. Photomicrographs were taken using the NIS Elements AR 2.20 software. Scanning electron microscope (SEM) images and qualitative chemical analyses were performed on ore minerals at the Polish Geological Institute - National Research Institute on the Jeol JSM-6380LA electron microscope in energy-dispersive mode (EDS Link Analytical ISIS). Operating conditions were: $20 \mathrm{kV}$ accelerating voltage, $5 \mu \mathrm{m}$ spot size, and $6 \mathrm{nA}$ sample current. The ZAF-4 correction program was applied. Application of the arsenopyrite geothermometer, despite its limitations, allowed the determination of crystallisation temperatures of arsenopyrites from the Złoty Stok deposit and the Bardo Śląskie and Mąkolno prospects. The As/S ratio of the arsenopyrite coexisting with other phases in the system As-S-Fe has been proposed as a geothermometer (e.g., Kretschmar and Scott, 1976; modified by Sharp et al., 1985). The application of the elaborated diagrams requires the use of the international arsenopyrite standards (asp 57 and/or asp 200) and a very precise selection of materials before the microprobe measurements.

Quantitative chemical analyses (EPMA - Electron Probe Micro-Analysis) of gold and telluride grains were made using the CAMECA SX100 electron microprobe in PGI-NRI. Operating conditions for EPMA were: $25 \mathrm{kV}$ accelerating voltage, $20 \mathrm{nA}$, primary beam current, $25 \mathrm{sec}$ counting time, and detection limits (wt.\%) for $\mathrm{Au}-0.121$ and for $\mathrm{Ag}-0.033$.

Geobarometric measurements on samples supplied by the authors were made by Prof. A. Kozłowski (unpublished reports). Fluid inclusion studies were carried out on specimens from scheelite-bearing quartz veins, from the Ptasznik prospect and from quartz veinlets from the Dębowinka prospect. The routine heating-freezing microscope runs were performed (Roedder, 1984). In all samples, only primary inclusions were considered for this study. homogenisation temperatures were measured with use of microscopic thermocamera made by Fluid Co. This allowed for a very high accuracy of temperature determination of $\pm 1^{\circ} \mathrm{C}$. The homogenisation temperature (Th) of carbon dioxide inclusions used for $\mathrm{P}$ determination was made with accuracy of $\pm 0.1^{\circ} \mathrm{C}$. Inclusions in scheelite were small, usually not exceeding $10 \mu \mathrm{m}$ in length. They were frequently euhedral (negative crystals) of isometric and tabular habits. The results of the fluid inclusion studies of quartz and scheelite from quartz-feldspar veinlets hosted by variable rocks are given in Appendices 7 and 9.

\section{RESULTS - ORE MINERALISATION AND METASOMATIC PROCESSES}

The variable types of ore mineralisation that occur in different regions of KZS and its contact aureole will be discussed on the best-documented examples. They include (1) the Złoty Stok-Skrzynka Shear Zone (eastern and southeastern aureole; Złoty Stok and Lutynka abandoned deposits and outcrops near Droszków-Skrzynka-Ołdrzychowice), (2) the northern part of the KZS pluton represented by the Bardo Śląskie and Dębowinka prospects; the Podzamek Quarry, and (3) metamorphic roof blankets patchily distributed on the KZS granitoid pluton (Mąkolno and Ptasznik prospects) and (4) the central and southern parts of the KZS pluton represented by the Jaszkowa Górna prospects and the Żelazno area (Fig. 1).

\section{ZŁOTY STOK-SKRZYNKA SHEAR ZONE (STRONIE SERIES)}

The Stronie Series is composed of Paleozoic metasedimentary rocks intercalated with various amounts of metavolcanites. Typical profile includes: mica schists, two-mica paragneisses, quartzites, marbles, erlanes, amphibolites and amphibolite schists. The Stronie Series represents mostly a low-temperature sector of the amphibolite mineral facies (Smulikowski, 1979). Close to the investigated area, the metamorphic complex contains also two small granitoid bodies: granodiorite and tonalite from Bielice and tonalite and granodiorite of Jawornik (Białek and Werner, 2004). Post-mylonitic evolution of the Stronie Series is closely related to KZS pluton emplacement (Mazur et al., 2015 and references therein). Its contact-metamorphic influence has been superimposed on the preceding regional metamorphism. The degree of this influence depended on the rank of earlier regional metamorphic transformations. The Złoty Stok-Skrzynka regional 
Shear (dislocation) Zone and related faults were the especially active lines for the thermal and metasomatic activation (Cymerman, 1996). Metasomatic processes are marked by increasing amounts of diopside, tremolite, almandine, cordierite, vezuvianite, quartz, fluorite, calcite and adularia (Wierzchołowski, 1976). However, the most important signs of metasomatic processes are different types of ore mineralisation. They include commercial ore bodies; vein type mineralisation; small stockworks and encrustations; as well as disseminated accessory ore minerals common in some country rocks. The examples of this variable ore mineralisation will be discussed below.

\section{ZŁOTY STOK Au-As DEPOSIT}

The Złoty Stok Au-As deposit is located on the eastern exocontact zones of the KZS granitoid pluton (Fig. 1). The Złoty-Stok contact-metasomatic aureole is composed mainly of garnet-cordierite hornfelses, hercynite-corundum hornfelses, skarns, skarnoids, marbles, reaction granitoids and various pyroxene-plagioclase rocks (Wierzchołowski, 1976). The Złoty Stok ores occur in four separate fields known as the Western, Eastern Krzyżowa Hill (Fig. 2), Sołtysia Hill and Biała Hill, which cover about $3 \mathrm{~km}^{2}$ (unpublished mining materials; Bałdys, 1947). Three principal ore types are recognized: (1) löllingite-arsenopyrite rich skarns which envelope lenses of dolomitic marbles (Fig. 3A, B); (2) elongated ledges of diopside-tremolite pyrrhotite-magnetite ores with thick spots and nests of ore minerals (Fig. 3C, E); and (3) disseminated arsenic ores related mainly to slightly serpentinized dolomitic marbles and strongly serpentinised black ultramafic rocks (Fig. 3F, H). The vein-type ore mineralisation is less abundant and occurs locally in quartz and pegmatite veins (Mikulski and Speczik, 2008).

The ores differ in grade and composition. Massive skarn-type ores (35-40\% As) very rich in löllingite dominate at the Western Ore Field. They form zones of skarns that enve- lope stocks or lenses of dolomitic marbles. The lenses of dolomitic marbles are on average 100-130 m in length and from 15 to $25 \mathrm{~m}$ in thickness (Kowalski, 1963). Dolomitic marbles are enveloped with a black serpentinite crust that grades outwards into a green one and then into grey-green calc-silicate rocks, $1-3 \mathrm{~m}$ thick. The richest mineralisation is present in black serpentinites where the average content of As-bearing minerals varies from 30 to $40 \mathrm{wt}$ \% with associated Au enrichment that reaches up to ca. $30 \mathrm{ppm}$ (Mikulski, 1996a). Green serpentinites have poorer Au grades and contain massive löllingite aggregates with the As content that vary from 7 to 20 wt.\%. Rich laminated ores $(7-10 \%$ As) associated with zones of serpentinisation are major ore types in the Eastern Ore Field, where, in contrast to the Western Ore Field, arsenopyrite and $\mathrm{Cu}$-sulphides dominate over the löllingite.

The Soltysia Hill Ore Field constitutes one elongated ledge of diopside-tremolite rocks with thick spots and nests of ore minerals. Low-grade disseminated type mineralisation dominate the Biała Hill Ore field, which is a large stock of dolomitic marbles with week symptoms of serpentinisation. In calc-silicate rocks the mineralisation is mostly of impregnation type with the As contents not exceeding $7 \mathrm{wt} . \%$. Disseminated low-grade ores associated with the most extensively mined dolomitic marbles were found occasionally in non-excavated country rocks, mainly in the mica schists containing zones of graphite, garnet and As-Au mineralisation. Arsenic-bearing minerals are also common in aplite, pegmatite, and other vein-type rocks including quartz and spessartite veins, which occur throughout the area. The exploration results from the 1990s showed that $\mathrm{Au}$ occurs also in significant quantities (from 0.5 to $5 \mathrm{ppm}$ ) in pyrrhotite and magnetite-type mineralisation that is commonly associated as independent lenses (Muszer, 1992). These works also show that the löllingite/arsenopyrite mineralisation dominates also in pegmatitic stocks of the Golden Creek (Złoty potok) Quarry and in the Western Ore Field.

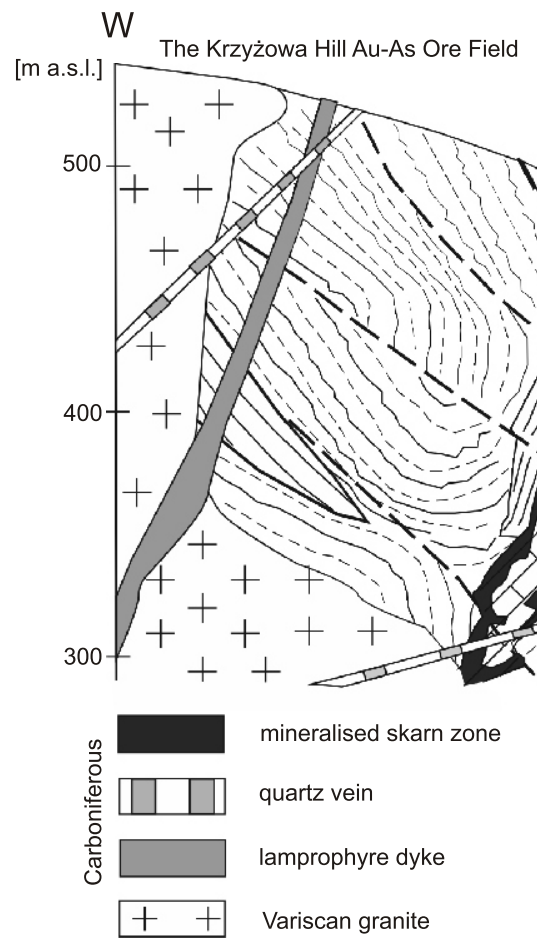

Fig. 2. Schematic cross-section through the Krzyżowa Hill Ore Field of the Złoty Stok Au-As deposit (modified after unpublished mining materials) 

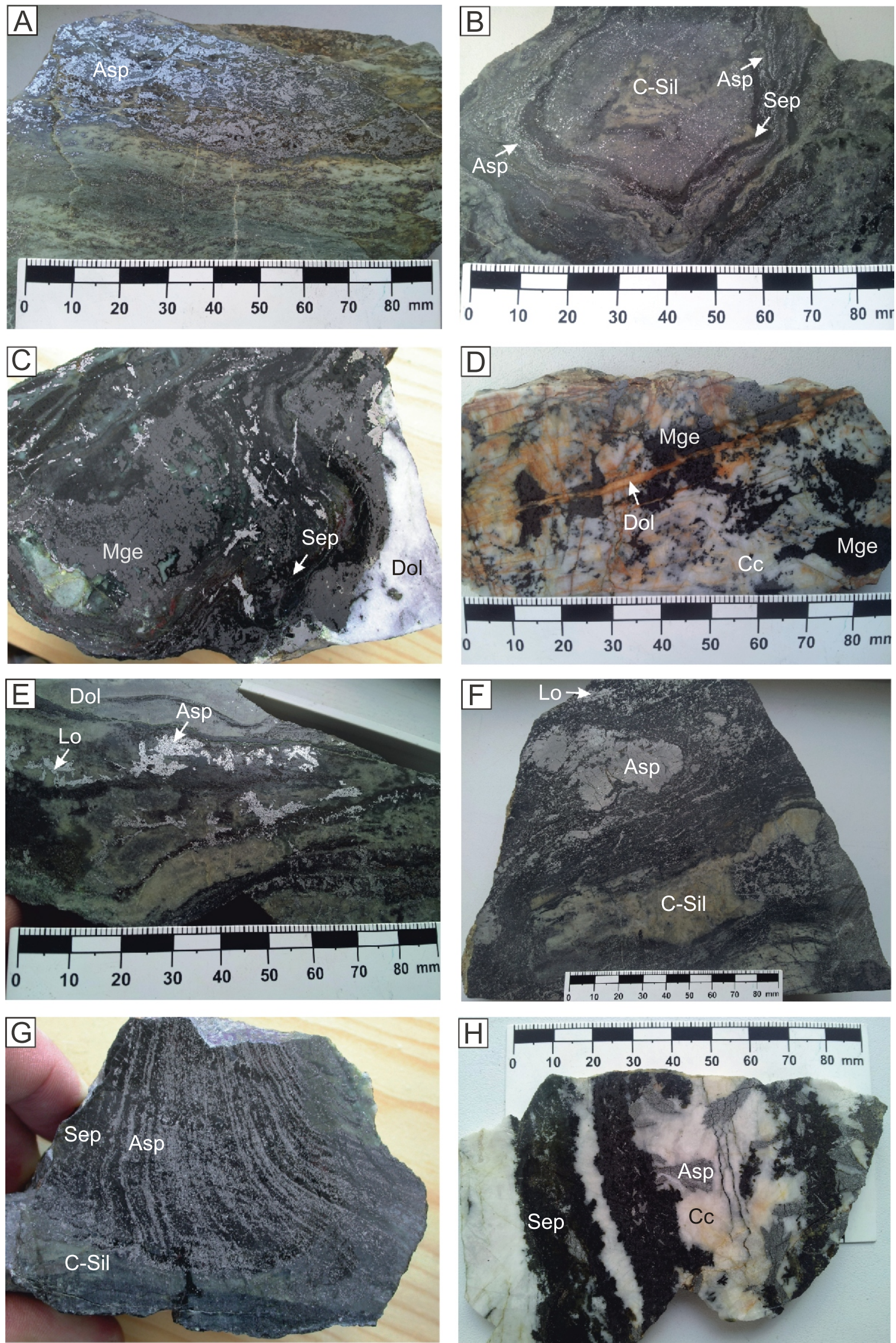

Fig. 3. Photograps of characteristic arsenic and magnetite ores from the Złoty Stok deposit

A - gold-bearing löllingite-arsenopyrite ore hosted by calc-silicate rocks; B - typical "fluidal texture" of arsenic ores and black serpentinite in calc-silicate rocks; $\mathbf{C}$ - magnetite ore surrounded by serpentinite in dolomitic marble; $\mathbf{D}$ - calcite-dolomite marble with magnetite mineralisation; $\mathbf{E}$ - arsenic ore along contact of dolomitic marbles with calc-silicate rock; $\mathbf{F}$ massive arsenopyrite ore hosted by cataclased calc-silicate rock; $\mathbf{G}$ - black serpentinite laminas with arsenopyrite in calc-silicate rocks; $\mathbf{H}$ - recrystallised calcite with arsenopyrite ores and black serpentinite laminas; Asp - arsenopyrite, Cc - calcite, C-Sil - calc-silicate rock, Dol - dolomite, Lo - löllingite, Mge - magnetite, Sep - serpentinite 
The main ore mineral in Złoty Stok is löllingite accompanied by various amounts of arsenopyrite, magnetite, pyrrhotite, and pyrite (Fig. 4A-D). Both löllingite and pyrrhotite often bear symptoms of desulphurisation. Other ore minerals, such as chalcopyrite, galena, sphalerite, hematite, scheelite and glaucodote were reported in smaller quantities (Kowalski, 1963, 1969; Budzyńska, 1971; Mikulski, 1996a; Muszer, 1997). Secondary minerals are: goethite, scorodite, jarosite, malachite, azurite, covellite, chalcocite and asbolane.

Arsenic ore is dominated by large löllingite crystals (2-4 mm) elongated along the $z$-axis, which form pinacoids and prisms. These crystals usually form parallel-oriented aggregates composed of several to tens of individual crystals. There were three arsenopyrite generations recognized at Złoty Stok. The first one (Asp I) is strongly correlated with the löllingite crystallisation. BSE images indentified variable zoning patterns of arsenopyrite due to changes in As/S ratios. Arsenopyrite (Asp I) occurs as intergrowths with löllingite that fill fissures and voids in cracked grains of löllingite, and in younger arsenopyrite (Asp II) grains that often host relics of löllingite in their central parts (Fig. 4E, F). Within this generation of arsenopyrite (Asp I), native gold inclusions are observed. Scanning electron microscope studies of arsenopyrites allow detecting compositional differences among them, which are shown on the ternary As-Fe-S phase diagram in Figure 5A (see also Appendix 1). Arsenopyrite I could have originated at high temperatures of $>550^{\circ} \mathrm{C}$ as estimated using the arsenopyrite geothermometer (löllingite-arsenopyrite buffering curve) after Kretschmar and Scott (1976). The As/S ratio of the arsenopyrite coexisting with other phases in the system As-S-Fe has been experimentally calibrated as a geothermometer, however, the application is limited mostly by the widespread presence of significant amounts of other elements within arsenopyrite. Furthermore, arsenopyrite is very often zoned with respect to As content, and true buffered assemblages are often hard to find. Within the studied samples from the KZS area, only some of the arsenopyrite grains disseminated in calc-silicate rocks from the Złoty Stok deposit seem to be suitable for the As/S ratio geothermometry; the majority being excluded because of high Co contents. The arsenic atomic content of Asp I is typical for the western part of the deposit directly along the contacts with the KZS granitoids. Arsenopyrites of the second generation (Asp II) have lower arsenic contents ( 34.5 to $\sim 36$ a.p.f.u. at. $\%$ As). They occur more commonly in silicified zones and in quartz veins and they formed in the temperature range of $\mathrm{ca}$. $470-530^{\circ} \mathrm{C}$ using löllingite-arsenopyrite buffering curve. The 3rd generation of arsenopyrites (Asp III) occurs in quartz veinlets as separate individual crystals associated with pyrite. Asp III is characterized by low As content ( 32 a.p.f.u. As) and may have crystallised at ca. $450 \pm 30^{\circ} \mathrm{C}$.

Paragenetic association of magnetite, pyrite and pyrrhotite occurs as either monomineral or poly-mineral massive impregnated and cataclased ores. Arsenopyrite is generally younger than löllingite, which together with commonly oriented intergrowths of chalcopyrite in pyrrhotite may suggest high $\left(>400^{\circ} \mathrm{C}\right)$ temperatures of metasomatic processes during the formation of the pyrrhotite-associated minerals (Mikulski, 1996a). Magnetite-rich mineralisation in dolomitic marbles is characterized by increased amounts of organic material, while in the samples with rich arsenic ore the content of organic matter is lower (Mikulski and Speczik, 2008). At the Złoty Stok deposit the main magnetite generation occurs together with pyrrhotite. Such magnetite-pyrrhotite ores were the subject of exploitation. This magnetite is of metasomatic origin.

Gold in the Złoty Stok deposit. In the Złoty Stok deposit, four generations of gold are recognized: refractory (chemically bound - Au I), nonrefractory (visible under microscope - Au II, Au III and Au IV; Muszer, 1992; Niczyporuk and Speczik, 1993; Mikulski, 1996a). The main gold-bearing minerals are löllingite, which contains on average about $30 \mathrm{ppm}$ of $\mathrm{Au}$, and arsenopyrite (with elevated Co admixture). Co-arsenopyrite contains from 5.2 to $34.8 \mathrm{ppm}$ Au. Gold occurs as finely dispersed submicroscopic particles within these ore minerals that were formed at a high-temperature stage of ore precipitation. Gold admixtures range from $0.72 \mathrm{wt} . \%$ in löllingite to $0.8-1.4 \mathrm{wt} . \%$ in arsenopyrite and from ca. $0.4 \mathrm{wt} . \%$ in arsenian sulphosalts of $\mathrm{Ni}-\mathrm{Fe}-\mathrm{Co}$ to $0.9-2.2 \mathrm{wt}$.\% in bismuthinite. Non-refractory gold of the 2nd and 3rd generations has different forms (inclusions, veinlets, intergranular - "free-gold") and is represented mostly by electrum and minor maldonite. Inclusions of $(0.5-15 \mu \mathrm{m}) \mathrm{Au}$ II have been found in löllingite, arsenopyrite, pyrrhotite, magnetite, Ni-Co sulphoarsenides, limonite, quartz and garnet (Fig. 4G). Au II generation contains silver admixtures (up to $27 \mathrm{wt} . \%$ in löllingite and up to $13 \mathrm{wt} . \%$ in arsenopyrite). Bismuth (7-35 wt.\%) and copper (up to $18.5 \mathrm{wt} . \%$ ) admixtures were also detected in gold. Gold inclusions in arsenopyrite (up to $10 \mu \mathrm{m}$ in size) are associated predominantly with native bismuth. The common association between gold and bismuth has been seen in many ore deposits, and results from the scavenging of gold from hydrothermal fluids by liquid bismuth (e.g., Ciobanu et al., 2006; Cockerton and Tomkins, 2012).

Silver contents in gold vary in a wide range and may reach ca. 32 wt. \% indicating electrum. The most common form of individual $\mathrm{Au}$ III occurrences in arsenic ore are ellipsoidal Au inclusions in quartz that heals cataclased löllingite grains. Moreover, numerous grains of native gold were also observed in quartz \pm calcite veinlets. They are from 5 to $50 \mu \mathrm{m}$ in size, mostly have ellipsoidal shape with more or less regular edges and are characterized by more intense yellow colour and lower admixture of silver and other elements. It is suggested that gold originally dispersed in löllingite was remobilized and concentrated in minute quartz/carbonate veins during the later metasomatic stages, or as a result of hydrothermal activity within shear zones, during post-Variscan times. Gold mobilization from primary ore minerals is a well known process (e.g., Möller and Kersten, 1994). The latest generation of gold (Au IV) at the Złoty Stok deposit (gold grains with 4.5-7 wt.\% of Ag admixture) was also found in goethite veinlets that cut weathered arsenic ores.

Geochemical features of gold ores. Gold contents in ores show a strong correlation with As contents $(c c=0.57 ; n=73)$, what is confirmed by mineralogical and microprobe studies, which show that gold associates with löllingite and arsenopyrite mineralisation (Mikulski, 2001). Gold concentrations ranged from $0.073 \mathrm{ppm}$ to $40.0 \mathrm{ppm}(n=88$; arithmetic average $=$ 3.91 ppm Au; Fig. 6A; Appendices 2-4). The highest gold concentration occurred in arsenic ores (10-40 ppm) and the lowest one in magnetite \pm pyrrhotite \pm pyrite ores (usually $<1 \mathrm{ppm}$ ). If magnetite-pyrrhotite ore is overprinted by arsenic mineralisation, the contents of gold are increased at least several times. There is a positive correlation of gold with $\mathrm{Bi}(c c=0.92 ; n=21$; Fig. $6 \mathrm{~B}), \mathrm{Y}(\mathrm{cc}=0.87 ; n=29)$ and weaker with $\mathrm{V}(c c=0.44$; $n=50), \mathrm{Cd}(c c=0.35 ; n=50), \mathrm{SiO}_{2}(c c=0.35 ; n=65)$ and $\mathrm{MgO}$ $(c c=0.22 ; n=29)$. Recent studies in the Złoty Stok deposit revealed that the content of organic carbon (TOC - Total Organic Carbon) decreased in zones of gold enrichment (Mikulski and Speczik, 2008). Similar relationship was also reported from other deposits (Gize, 1999). There is a positive correlation between $\mathrm{TOC}$ and $\mathrm{MgO}$ and $\mathrm{Fe}_{2} \mathrm{O}_{3}(c c=0.54$ and $0.52 ; n=50)$ (Fig. 6C, D). In contrast, the correlation of $\mathrm{TOC}$ with $\mathrm{SiO}_{2}$ and $\mathrm{CaO}(c c=-0.58$ and -0.28$)$ is negative. This suggests that increased amount of $\mathrm{MgO}$ has been connected with serpentini- 

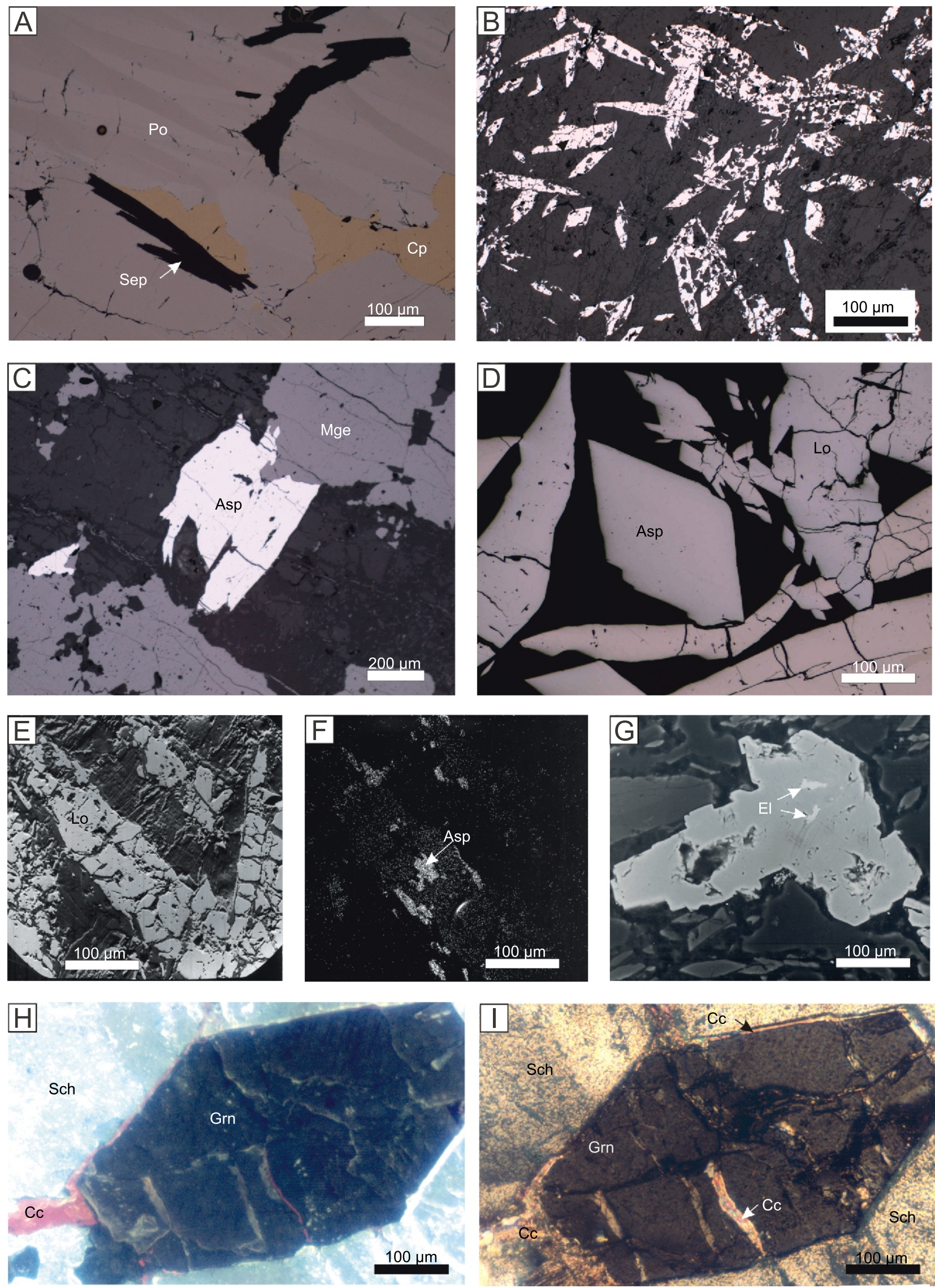

Fig. 4. Microphotographs in reflected light (A-D) of ore minerals from the Złoty Stok deposit

A - intergrowths of pyrrhotite with chalcopyrite; B - skeletal crystals of löllingite replaced by serpentine minerals; C - arsenopyrite overgrowths on magnetite; BSEI - Backscattered Electron Image; D - euhedral crystals of arsenopyrite and fractured löllingite; E BSEI of fractured löllingite crystals; $\mathbf{F}$ - map of sulphur distribution with bright colours indicating the presence of arsenopyrite within large löllingite crystals; G - BSEI of Ni-Co sulphosalts with electrum inclusions; $\mathbf{H}, \mathbf{I}$-garnet intergrowths with scheelite cut by calcite microveinlets, image in the cathodoluminescence $(\mathrm{H})$ and transmitted light (I); Cp - chalcopyrite, El - electrum, Po - pyrrhotite, Sch scheelite, other explanations as in Figure 3 

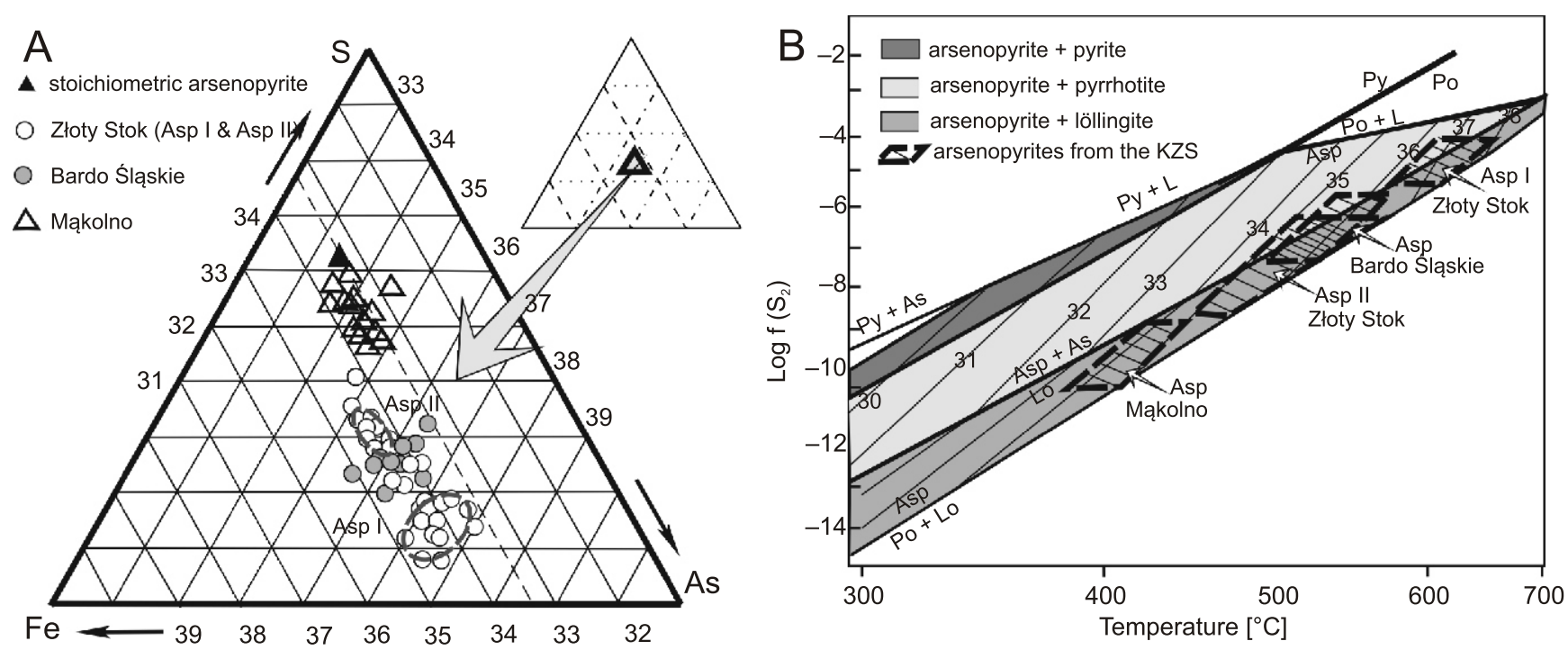

Fig. 5. Arsenopyrite geothermometer

A - arsenopyrite compositions (at.\%) from the KZS in the ternary system Fe-As-S; coexisting phases shown in parentheses (acc. to Sharp et al., 1985); B - phase diagram showing the dependence of As (at. \%) in arsenopyrite from sulphur fugacity and temperature during arsenopyrite precipitation in the KZS area; phase boundaries and arsenic isopleths based on data of Kretschmar and Scott (1976); L-sulphur-arsenic liquid, Py - pyrite, As - at.\% As in arsenopyrite; other explanations as in Figures 3 and 4

A

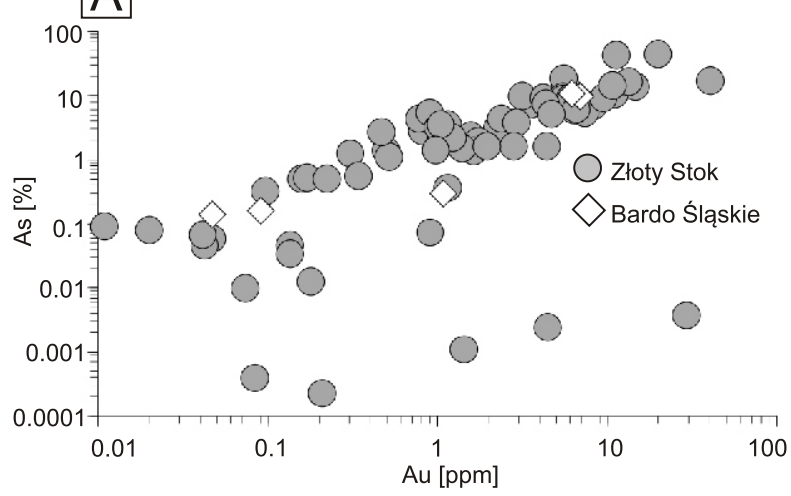

C

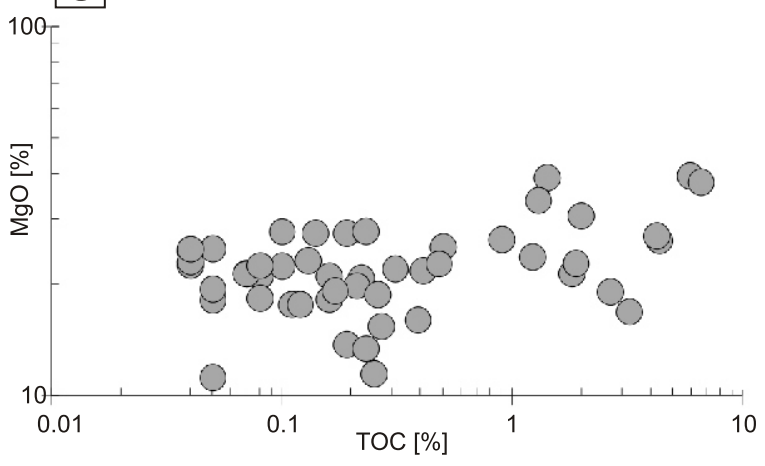

B

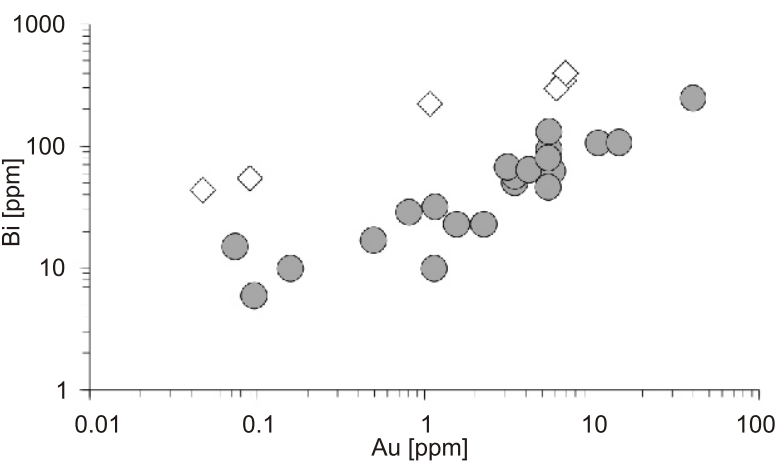

D

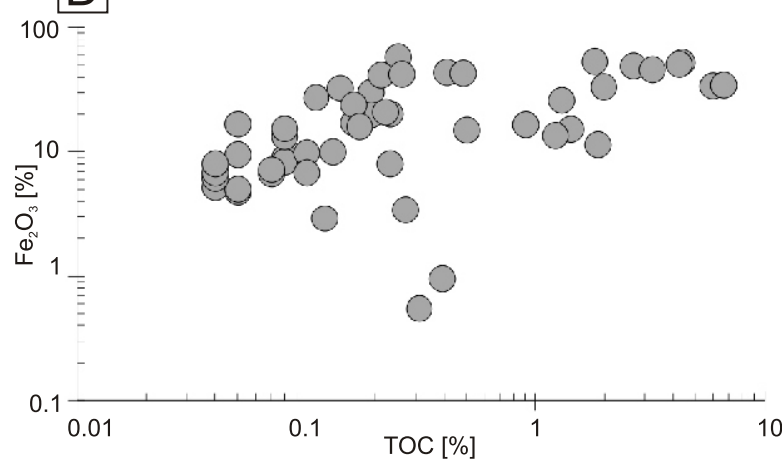

Fig. 6. Logarithmic plots of Au against $A s(A)$ and $B i(B)$ for the Złoty Stok deposit and Bardo Śląskie prospect, and logarithmic plots of TOC (Total Organic Carbon) versus $\mathrm{MgO}(C)$ and $\mathrm{Fe}_{2} \mathrm{O}_{3}(\mathrm{D})$; for the same samples 


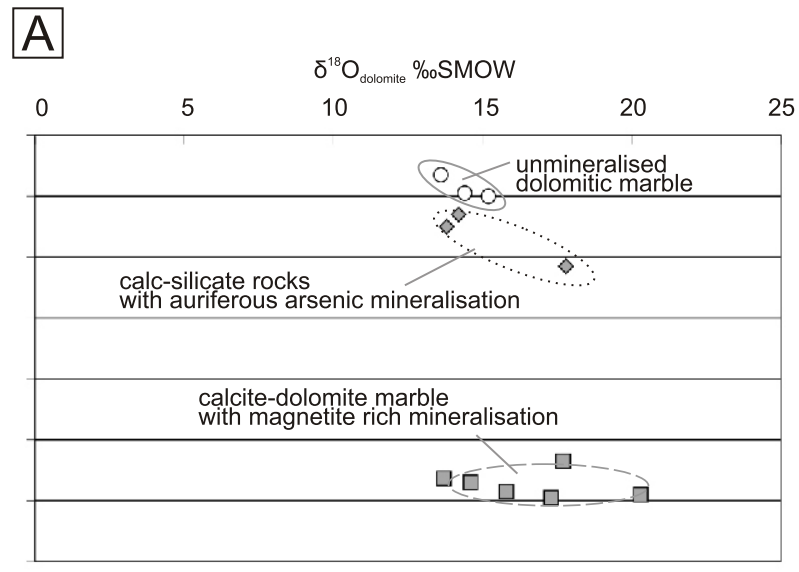

calcite-dolomite marble with magnetite rich mineralisation
B

$25 \quad-30$

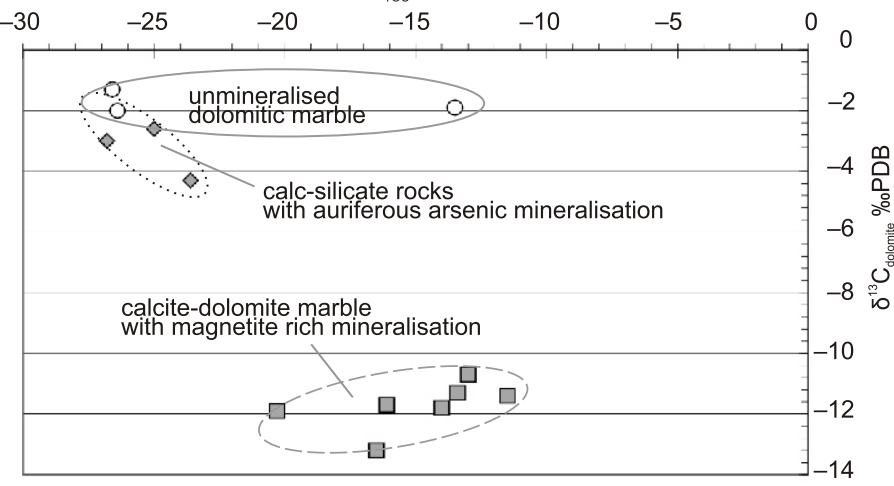

calc-silicate rocks

with auriferous arsenic mineralisation

Fig. 7. Binary plots of $\delta^{18} \mathrm{O}_{\text {dolomite }} \mathrm{SMOW}$ versus $\delta^{13} \mathrm{C}_{\text {dolomite }}$ PDB (A) and of $\delta^{13} \mathrm{C}_{\text {Toc }}$ PDB versus $\delta^{13} \mathrm{C}_{\text {dolomite }}$ PDB (B); modified after Mikulski and Speczik (2008)

sation processes of dolomitic marbles. Serpentinisation caused decalcification of carbonaceous rocks. Subsequent processes of carbonate rocks silicification associated with the KZS granite intrusion caused remobilization of organic matter and its redistribution within brecciated rocks. Geochemical studies indicate that the $\mathrm{Au} / \mathrm{Ag}$ ratio in ore-grade materials (>1 ppm Au) averages at $6: 1(n=47)$.

Genesis of ore mineralisation at the Złoty Stok deposit Mineral paragenesis of gold-bearing ore mineralisation at the Złoty Stok deposit formed during two main separate stages. Stage I of skarn-like mineralisation was due to metasomatic processes developed in the exocontact zone of the Variscan KZS pluton. Fluid inclusion studies demonstrate that the earliest phase of this stage, characterized by crystallisation of pyroxene, garnet and scheelite, were related to low salinity fluids (4.9-5.2 wt.\% $\mathrm{NaCl}$ equiv.) at temperatures between 464 and $480^{\circ} \mathrm{C}$ and pressure $<1.4 \mathrm{kbar}$ (Mikulski, 1996a). During later phases of this stage, widespread gold-bearing ore mineralisation (löllingite-arsenopyrite) was formed. The majority of gold occurs as fine-dispersed submicroscopic particles within ore minerals in black serpentinite, skarns and calc-silicate rocks. The $\delta^{18} \mathrm{O}$ values of dolomite of non-mineralised and slightly mineralised dolomitic marble range from +13.6 to $+15.2 \%$ SMOW, while mineralised samples of calcite-dolomite marble and calc-silicate rock have values from +13.7 to $+20.3 \%$ o SMOW (Fig. 7A; Mikulski and Speczik, 2009). A similar difference between samples was found for the $\delta^{18} \mathrm{O}$ values of calcite. This implies the $\delta^{18} \mathrm{O}$ values of all investigated samples from the ore zone area were affected by the ore-forming events. The $\delta^{18} \mathrm{O}$ values of carbonates $(+13.6$ to $+21.1 \%$ SMOW; Fig. 7 and Appendix 5) are generally comparable with those from other skarn-type deposits (Kwak, 1987). The $\delta^{13} \mathrm{C}_{\text {dolomite/calcite }}$ values of investigated calcite and dolomite (from -12.4 to -10.4 and from -13.2 to $-10.7 \%$ o VPDB, respectively; Fig. $7 \mathrm{~A}, \mathrm{~B}$ ) from dolomite marbles with magnetite-rich ores are more characteristic of hydrothermal fluids. These values were explained as a result of combined interaction of several processes, including dolomitisation, serpentinitisation, de-dolomitisation and isotope exchange reactions between minerals and fluids, due to thermal and subsequent hydrothermal influence of Variscan granitoids with partial oxidation and mobilisation of organic matter (Mikulski and Speczik, 2008). Moreover, an influx of freshwater during the later phases of skarn formation cannot be excluded, as mineralised samples are related to a fracture zone where the influence of such fluids is always possible. The sulphur isotope composition of arsenopyrite ranges from -3.05 to $3.68 \% \delta^{34} S$ CDT and of pyrrhotite from -4.27 to $0.35 \% \circ \delta^{34} S$ CDT. This suggests a magmatic source of sulphur with contribution from country rocks (Fig. 8 and Appendix 6).

The brittle deformation and hydrothermal infill by mineralising fluids related to the development of shear zones was responsible for the younger stage (II) with several phases of veinlet-impregnation type of minor ore mineralisation. Fluid inclusion studies of quartz veinlets in the auriferous samples indicated clearly the presence of three quartz generations which crystallised in different temperature ranges. Primary fluid inclusions homogenised in the liquid phase. The high-temperature quartz crystallised at temperatures from 384 to $429^{\circ} \mathrm{C}$ from high-salinity fluids containing from 13.1 to 14.5 wt. $\% \mathrm{NaCl}$ equivalent of total salts (Fig. 9 and Appendix 7) under pressure of 0.9 to $1.1 \mathrm{kbar}$. It may contain auriferous As mineralisation (arsenopyrite). The medium temperature quartz revealed

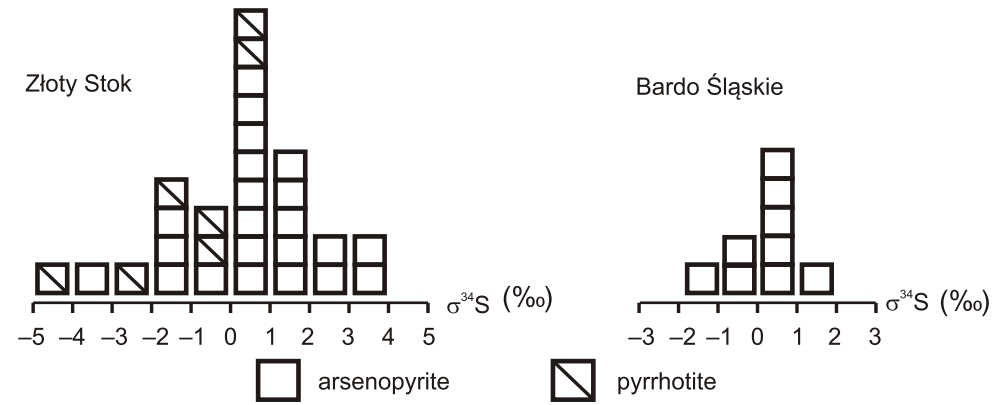

Fig. 8. The $\delta^{34} \mathrm{~S}$ value histograms (in \%o) for arsenopyrite and pyrrhotite from gold-bearing arsenic polymetallic ores in the Złoty Stok deposit and the Bardo Śląskie prospect 


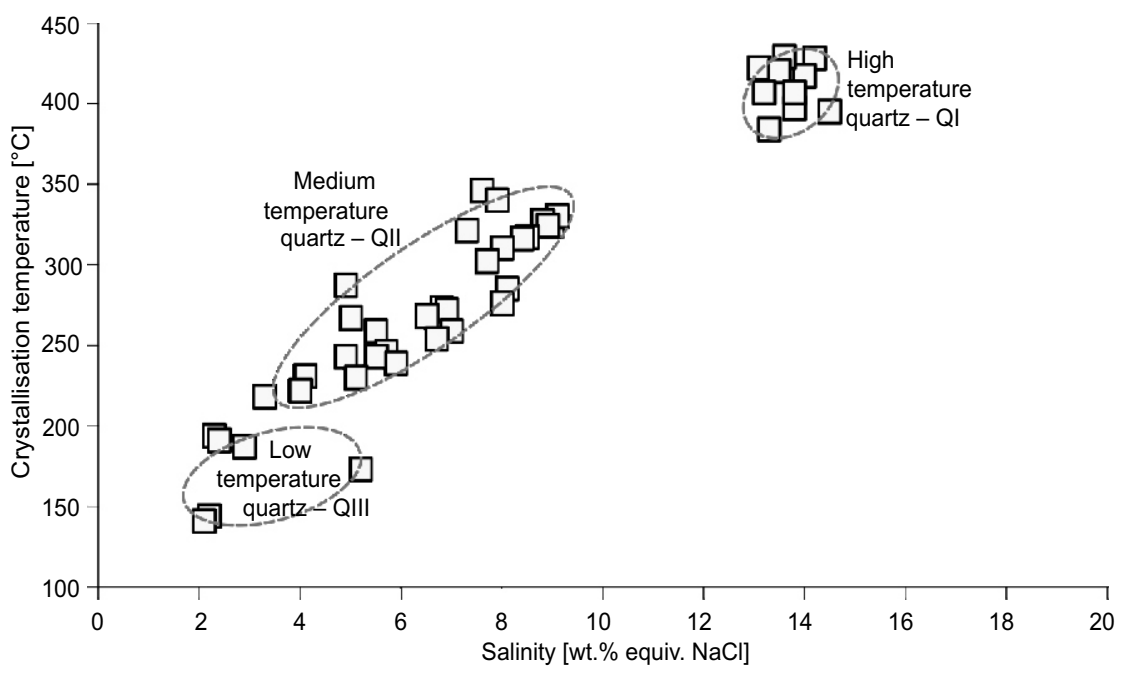

Fig. 9. Crystallisation temperatures versus salinity of fluid inclusions in quartz from three different stages (QI, QII and QIII) at the Złoty Stok Au-As deposit (after Mikulski and Kozłowski, 2011)

crystallisation temperatures from 230 to $346^{\circ} \mathrm{C}$ and crystallised from medium-salinity fluids from 5 to $9.1 \mathrm{wt} . \% \mathrm{NaCl}$ equivalent when pressure dropped from 1.2 to $0.5 \mathrm{kbar}$. It is associated by auriferous arsenopyrite mineralisation. The low-temperature quartz generation is intimately associated with late carbonates. Temperature of crystallisation of this quartz based on fluid inclusion studies is from 141 to $231^{\circ} \mathrm{C}$, low-salinity fluids (2.1 to $5.2 \mathrm{wt} . \% \mathrm{NaCl}$ equivalent) of pressure from 0.4 to $0.9 \mathrm{kbar}$ are the parent medium for this mineral association.

Processes of redistribution of primary gold from löllingite-arsenopyrite mineralisation were widely developed. Precipitation of visible gold within sulphoarsenides and sulphides was carried out by sulphur-bearing solutions at $350-250^{\circ} \mathrm{C}$ and near-neutral to alkaline environments, with the dominant role of hydrosulphide complexes e.g., $\mathrm{Au}(\mathrm{HS})_{2}{ }^{-}$. Main primary sources of metals for both stages were probably the metal preconcentrations in volcano-sedimentary rocks with mantle contribution $(\mathrm{Ni}, \mathrm{Cr}, \mathrm{Pt}$ and $\mathrm{Pd}$ ), which later underwent mobilisation due to the formation of hybrid granitoid intrusions and development of shear zones. However, the REE-patterns of the mineralised samples point to a granitic source of the studied orebodies (Mikulski and Speczik, 2008). Moreover, the correlation coefficients are very high for REE and $\mathrm{As}, \mathrm{Au}, \mathrm{Bi}, \mathrm{Fe}$ and $\mathrm{Mn}$ oxides $(r=0.95-0.85)$, indicating strong affinities of gold- and metal-bearing postmagmatic hydrothermal fluids with parental granitoids magmas.

\section{ABANDONED LUTYNKA Pb-Zn DEPOSIT}

The Lutynka $\mathrm{Pb}-\mathrm{Zn}$ vein deposit is situated ca. $8 \mathrm{~km} \mathrm{SE}$ from KZS outcrops within the Lądek-Śnieżnik metamorphic rocks, namely the Stronie Series (Fig. 1). The ores at Lutynka are connected with a zone of cemented tectonic breccia that is associated with a large fracture trending towards the NE. The thickness of breccia varies from $20 \mathrm{~cm}$ to $4 \mathrm{~m}$. The wall rocks are mostly quartz-muscovite-graphite schists with minor lenses of amphibolite and amphibolite schists. The breccia is cemented with skarn-type minerals, quartz and minor calcite. Inside the inner parts of the breccia zone, gangue minerals form individual veins, veinlets, lenticular bodies and druses. Two stages of ore formation were recognized at Lutynka. The first-stage minerals occur in wall rocks and in their fragments locked within the breccia zone (Olszyński and Speczik, 1993).
They consist of pyrrhotite, pentlandite, magnetite, ilmenite, ilmenorutile and pyrite with minor chalcopyrite. Minerals of this paragenesis are oriented parallel to the lamination and are unevenly dispersed. The mode of occurrence of the mineralisation suggests its origin due to regional metamorphism of a sedimentary-volcanic sequence. Minerals of the younger stage occur within the veins and inside the matrix of the breccia zone (salbands). They are divided into two generations. The first one with higher temperatures of formation (from $260-220^{\circ} \mathrm{C}$ based on fluid inclusion in quartz) is represented by arsenopyrite, pyrite and chalcopyrite; the second one with lower temperatures $\left(180-150^{\circ} \mathrm{C}\right)$ consists of tennantite, sphalerite and galena (Olszyński and Speczik, 1993). Drop of temperature was associated with relaxation of tension which resulted in cataclasis of older minerals and their healing by minerals of younger generation. The most plentiful ore mineral is galena with some crystals reaching up to $2 \mathrm{~cm}$ across.

\section{DROSZKÓW-SKRZYNKA-OKDRZYCHOWICE PROSPECTS}

Along the southern contact of the outcrops of the Kłodzko-Złoty Stok granitoids and metamorphic rocks of the Stronie Series from Droszków to Ołdrzychowice, traces of auriferous ore mineralisation have been found in the Złoty Stok-Skrzynka regional Shear Zone (Fig. 1). Near Droszków, some outcrops of strongly silicified amphibolite as well as large quartz boulders contain scheelite mineralisation with traces of gold (Mikulski, 2000). Gold assays in samples of scheelite-bearing rocks revealed a wide range of Au contents due to the nature of inhomogenous gold occurrence in quartz veins. Usually, samples are barren but rarely may show an increased gold concentration up to a few ppm. Gold was found under microscope in the form of irregular single micrograins from 5 to $25 \mu \mathrm{m}$ (<15 wt. \% Ag admixture) and as electrum (<30 wt. \% Ag) inclusions in fractured arsenopyrite. Ore minerals occur as infill in the intergranular space and as impregnation in quartz veinlets, and are represented by arsenopyrite, pyrite, scheelite and titanite. In parent rocks, ilmenite, pyrrhotite, chalcopyrite and magnetite occur. Gold-bearing arsenopyrite mineralisation was also found in this area in an outcrop of a few metres thick leptynite and blastomylonitic gneiss insert within mica schists (strike/dip: 50/45SE). Auriferous arsenopyrite of pillar-like habit 
and a length of $<1 \mathrm{~cm}$ commonly appears along fractures in leptynite. Intensive brownish color is very characteristic for fractured leptynite as a result of sulphide replacement by Fe-hydroxides - goethite. Gold assays revealed usually $<1 \mathrm{ppm}$ Au.

Moreover, two quartz veins with a thickness from 5 and $35 \mathrm{~cm}(60 / 90 ; 50 / 85 \mathrm{E})$, respectively, were found in the outcrop of mylonitic gneisses (60/35SE) near Skrzynka. Gold assays reach $0.5 \mathrm{ppm} \mathrm{Au}$. Gold concentration is associated with pyrite aggregates of about $2 \mathrm{~cm}$ across. Fresh pyrite grains contain up to $3.5 \mathrm{wt}$.\% Au and admixtures of $\mathrm{Cu}$ and $\mathrm{Ni}$. Pyrite is commonly replaced by Fe-hydroxides (goethite). Traces of gold in scheelite-containing quartz veins were also found in an outcrop located in Ołdrzychowice, north of the main road between Kłodzko and Lądek.

All other investigated locations (e.g., Sosenka, Trzebieszowice, Marcinków) situated along the SE boundary of the KZS pluton reveal common symptoms of ore mineralisation in metabasites. Ilmenite, rutile and magnetite generally prevail over pyrite, chalcopyrite and pyrrhotite. This mineralisation is similar to the pre-Variscan metamorphic-type mineralisation. However, in some locations, younger arsenopyrite aggregates with minor tennantite and chalcopyrite dominate, which are related to younger fractures.

\section{THE NORTHERN PART OF THE KZS GRANITOID PLUTON}

BARDO ŚLĄSKIE Au-As PROSPECT

Gold-bearing sulphide mineralisation was found in boudin-like boulder in the old rock fall materials uncovered in 1997 by the flood of the Nysa Kłodzka River near Bardo Śląskie in the NW part of the contact metamorphic aureole of the KZS pluton (Figs. 1 and 10A; Mikulski, 1998). The auriferous samples are strongly cataclased and represent fragments of silicified metasomatic rock. They have an ellipsoid-like form (ca. 0.4 $\times 0.6 \mathrm{~m}$ in size) and are variably weathered (Fig. 10B). Quartz and sulphides make up $30-50 \%$ of total rock volume. Other components are represented by calcite, chlorite, plagioclase, K-feldspar, muscovite, rutile, zircon, apatite and titanite. Plagioclases are subject to strong sericitisation. Moreover, strong metasomatic alteration is marked by the appearance of silica, sulphides, chlorite, calcite and prehnite. Primary auriferous sulphide mineralisation may occur in quartz-carbonate lodes or lenses within the WNW-ESE-trending tectonic zone that separates the Upper Devonian-Carboniferous flysch sedimentary rocks of the Bardo Structure from the Visean Graniec-Bardo apophysis (Mikulski and Williams, 2014a). The Graniec-Bardo apophysis is built of dark grey medium-grained and fine-grained tonalite and granodiorite. The apophysis is hosted by siliciclastic schists of the Mikołajowice Formation (Famennian) and rock series composed of intercalation of greywacke sandstones, clayey schists, mudstones and claystones (Visean; Oberc et al., 1994). These rocks along the contact with granodiorite underwent strong hornfelsisation. Flysch rocks are strongly folded, forming narrow sheeted thrusts and secondary synclinal folds (Oberc, 1972 Haydukiewicz, 1973, 1990; Wajsprych, 1978, 1986).

Gold mineralisation is associated with sulphide occurrences, which are dominated by arsenopyrite and pyrite. Gold inclusions, from 2 to $50 \mu \mathrm{m}$ across, commonly occur in arsenopyrite. Inclusions of electrum and native gold (with silver admixture up to a few percent and with traces of $\mathrm{Cu}$ ) occur in association with $\mathrm{Bi}$ - and Te-minerals. Gold concentrations in some parts of boudinage rocks may reach $7 \mathrm{ppm}(n=20)$. An arithmetic average is $1.3 \mathrm{ppm}(n=22)$. The highest gold concentration is observed in those parts of concretions which are not weath- ered and dominated by coarse-grained arsenopyrite mineralisation (from 2.25 to $6.7 \mathrm{ppm}$; arithmetic average for $n=5 \mathrm{sam}$ ples $\left.-x_{n=5}=3.83 \mathrm{ppm}\right)$. The lowest gold contents $\left(x_{n=5}=0.25\right.$ ppm) were determined in parts showing characteristic red-brownish colours and strongly weathered sulphides. Arsenopyrite commonly contains mono- or polymineral sulphide inclusions from 5 to $100 \mu \mathrm{m}$ in size (Fig. 10C-F). They include: pyrrhotite, base metal sulphides, native gold, electrum, native bismuth, bismuthinite, hedleyite $\left(\mathrm{Bi}_{2} \mathrm{Te}\right)$, tellurobismuthite $\left(\mathrm{Bi}_{2} \mathrm{Te}_{3}\right)$, pilsenite $\left(\mathrm{Bi}_{4} \mathrm{Te}_{3}\right)$, joseite $\mathrm{B}\left(\mathrm{Bi}_{4} \mathrm{STe}\right)_{3}$, rucklidgeite $(\mathrm{Bi}, \mathrm{Pb})_{3} \mathrm{Te}_{4}$, and Bi-sulphosalts (Fig. 11A and Appendix 11). Hedleyite $\left(\mathrm{Bi}_{2} \mathrm{Te}\right)$ commonly occurs with Bi-tellurides and gold in arsenopyrite (Mikulski, 2005b).

Gold was also found in quartz veinlets (ca. $2 \mathrm{~cm}$ thick) which cut granodirorite outcropping in Bardo Śląskie along the main road to Kłodzko. Granodiorite is impregnated by pyrite, and the concentration of $\mathrm{Au}$ in the rock was $1.5 \mathrm{ppm}$. Ore minerals are represented here by arsenopyrite, Co-arsenopyrite, pyrite and titanite, and less frequently by base metal sulphides (galena, sphalerite and chalcopyrite), stibnite, marcasite and Te-Bi minerals. Sulphides are intergrown with quartz, calcite and chlorite.

The gold mineralisation is of contact metasomatic type related to post-magmatic hydrothermal processes that developed after the formation of the Graniec-Bardo apophysis of KZS, which took place in the Mississippian. The early stage of contact metasomatism occurred at a high temperature much above $700^{\circ} \mathrm{C}$. The process led to the formation of not only the ore assemblage, but also rock-forming minerals. The arsenopyrite geothermometer indicates hydrothermal arsenopyrite crystallisation at a temperature above $500^{\circ} \mathrm{C}$ along the arsenopyrite + löllingite and arsenopyrite + pyrrhotite buffers (Kretschmar and Scott, 1976; Sharp et al., 1985). However, a constant cobalt admixture within most of the studied arsenopyrites from 0.6 to 2.9 atom. \% may limit such thermometry. The sulphur isotope composition of arsenopyrite ranges from -1.48 to $1.04 \%$ o $\sigma^{34}$ CDT and suggests a magmatic source of sulphur (Fig. 8). The presence of gold inclusions associated with $\mathrm{Bi}-$, and Te-minerals had retrogressive characters and occurred at a temperature probabty oxceeding $300^{\circ} \mathrm{C}$ in an intrusion-related gold system (Fig. 11B; Afifi et al., 1988; Cook and Ciobanu, 2004). The precise position and geometry of the ores and gold reserves have not been defined yet.

DĘBOWINKA GOLD PROSPECT

In the Sudetes a new type of contact metasomatic gold mineralisation - beresite - was described from Dębowinka (Mikulski, 1999b). Strongly altered gold-bearing quartzite with a characteristic greenish colour is called beresite by miners of the Beryozovskoye deposit in Urals (e.g., Czesnokow, 1973). Beresite consists mainly of quartz, sericite (ca. 20 wt.\%) and pyrite (several percent), and low quantities of rutile, titanite, plagioclase, muscovite, calcite and gold (from $>0.5$ up to a few $\mathrm{ppm})$. Dębowinka prospect is located in the central-western part of the Bardo Mountains unit (Fig. 1). Upper Devonian and Mississippian (Visean) flysch rocks predominate there, represented by siliceous schists, clayey schists, sandstones, greywackes and mudstones. These rocks are cut by Mississippian tonalite dykes and veins outcropping over a distance of 300 to $750 \mathrm{~m}$ along the NW-SE-running Dębowinka creek (Fig. 12A).

Ore mineralisation of impregnation-veinlet types occurs along tonalite outcrops within the zone of variable thickness up to a few tens of metres. Sulphide impregnation in the tonalite is rare. In the 18th century, a prospecting-exploratory adit was made for the purpose of antimony and silver extraction in this area (Dziekoński, 1972; Nejbert et al., 2013). Ore mineralisa- 

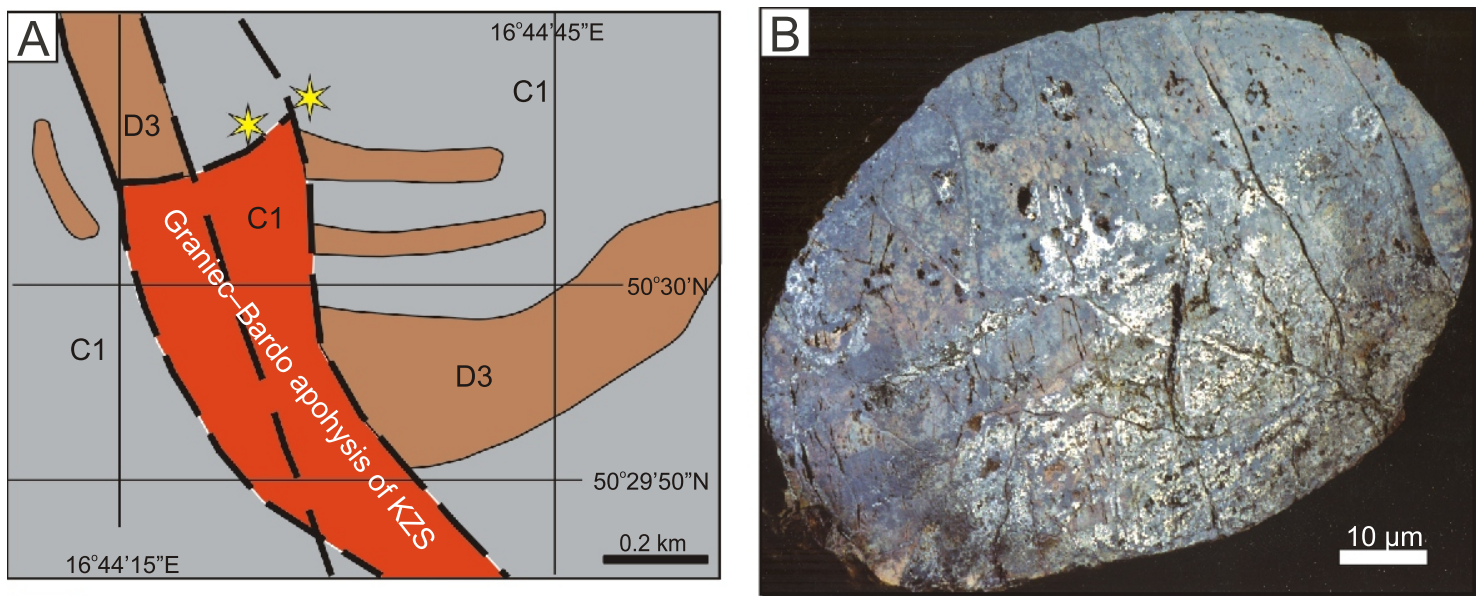

granodiorite and tonalite $(\mathrm{C})$

mudstone, greywacke and siliceous schist (C)

mudstone, claystone and siliceous schist (D3)

$s^{2}$ prospect with As-Au-Bi-Te mineralisation
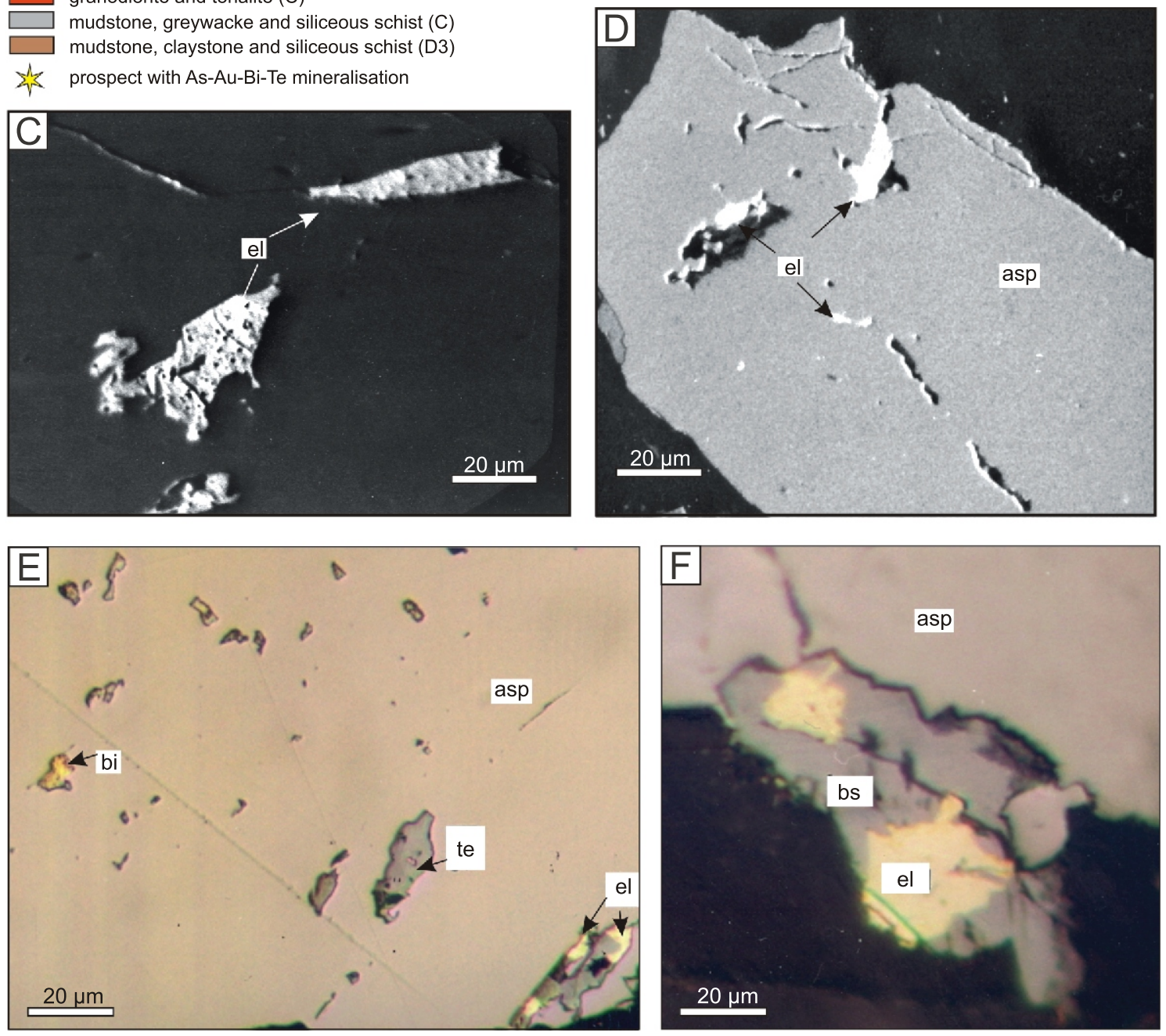

Fig. 10A - geological setting of the Bardo Śląskie gold prospect on the geological map according to Emerle-Tubielewicz (1979) and Oberc et al. (1994); B - photograph of auriferous-bearing sulphide mineralisation of contact metasomatic type from the Bardo Śląskie prospect; C-F - microphotographs of typical inserts of Au, $\mathrm{Bi}$ and Te-minerals in arsenopyrite ores

$\mathrm{Bi}$ - native bismuth; $\mathrm{Bs}$ - bismuthinite; Te - hedleyite, other explanations as in Figure 3 and 4; photo $\mathrm{C}$ and $\mathrm{D}$ backscattered electron image, photo $\mathrm{E}$ and $\mathrm{F}$ - photomicrographs in reflected light 

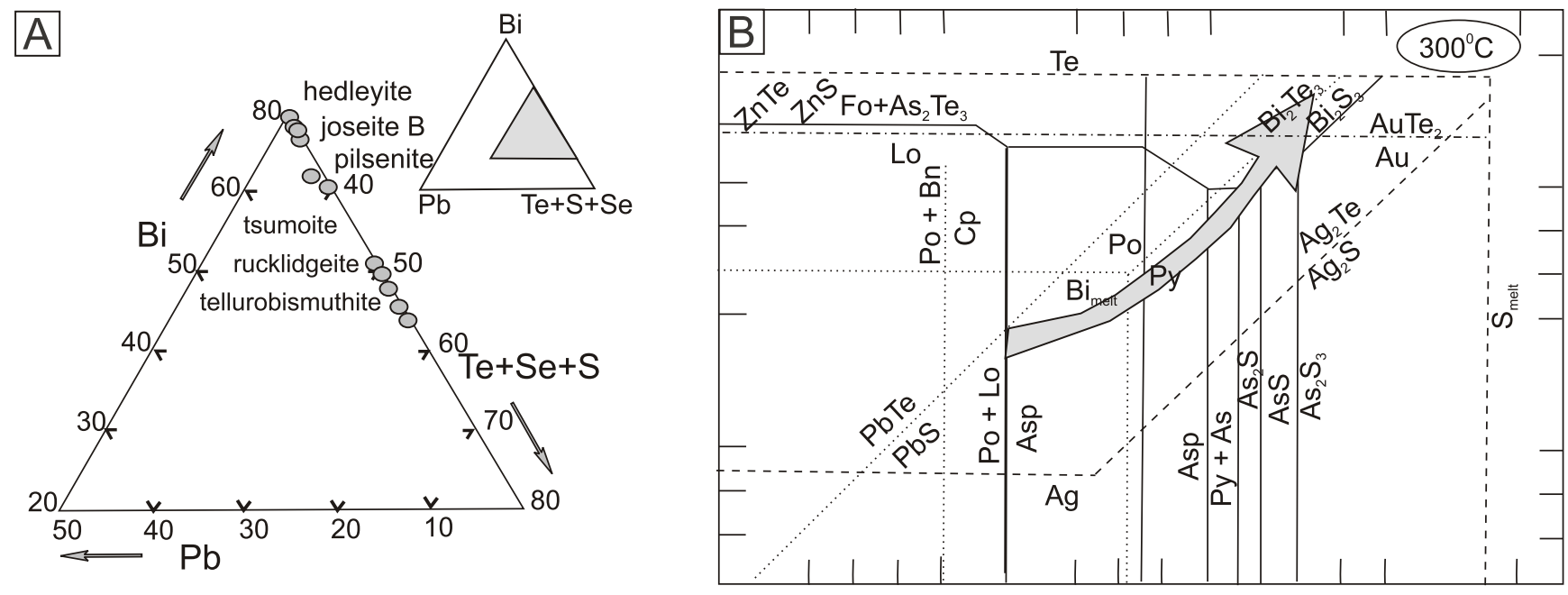

Fig. 11A - plot of various compositions of Bi-tellurides and tellurides in terms of $\mathrm{Bi}-\mathrm{Pb}-(\mathrm{S}+\mathrm{Se}+\mathrm{Te})$ from the Bardo Śląskie prospect; B - telluride-sulphide stability diagram at $300^{\circ} \mathrm{C}$ in $f \mathrm{Te}_{2}-\mathrm{fS}_{2}$ space, after Afifi et al. (1988)

Grey arrow indicates mineral phases relevant to the Bardo Śląskie prospect

tion may constitute up to several percent of rock volumes and may locally form nests or is situated concordant to laminas in mudstones, sandstones or schists. The richest sulphide impregnation occurs within light-colored greywacke sandstone inserts, 0.5-3.5 $\mathrm{m}$ in thickness (Fig. 12B). These sandstones are a member of the flysch unit (90-150/20-40 W). Strongly impregnated light greenish sandstones are classified as beresites with primary rock composition of quartz wakes. Beresite has a polygonal texture built by recrystallised quartz $\left(\mathrm{SiO}_{2}-\right.$ 44-48 wt.\%) and clayey-carbonate matrix $\left(\mathrm{Al}_{2} \mathrm{O}_{3}-16\right.$ wt.\%; $\mathrm{CaO}-9$ wt.\%; $\mathrm{Fe}_{2} \mathrm{O}_{3}$ and $\mathrm{K}_{2} \mathrm{O}$ about 10 wt.\%), which also recrystallised into sericite and calcite.

Beresite from Dębowinka contains from $210 \mathrm{ppb}$ up to $1.2 \mathrm{ppm}$ of gold. In beresites, the gold content depends on the occurrence of pyrite and other sulphides. Pyrite grains of variable size (from 0.1 to $3 \mathrm{~mm}$ across) impregnate beresite equally. Pyrite displays very characteristic skeletal habit as a result of its intergrowths with quartz and calcite (Fig. 12C). It may contain variable admixture of arsenic (up to $1.8 \mathrm{wt} . \%$ ), cobalt ( $<0.12$ wt. \%), nickel ( $<0.4$ wt. \%) and antimony $(<0.21$ wt. $\%)$. The back-scattered electron image (SEM-BSE) of pyrite is grey, however, it is possible to observe lighter parts which may indicate arsenic and gold admixtures. Microprobe investigation indicates that the highest contents of gold admixture in pyrite may be up to $0.06 \mathrm{wt} . \%$. Pyrite mineralisation is overprinted by younger generation sulphides of impregnation-veinlet character. Beresite is cut by numerous narrow quartz-carbonate (calcite, ankerite) veinlets with sphalerite, galena, boulangerite, jamesonite, stibnite, titanite, pyrite and chalcopyrite. Veinlet salbands show impregnation of coarse-grained minerals, which is represented mainly by stibnite and sphalerite (grains up to $3 \mathrm{~mm}$ across). There are also numerous grains of rutile, titanite and less frequent chalcopyrite, galena, pyrite and arsenopyrite (Fig. 12D). Rare inclusions of electrum, up to $10 \mu \mathrm{m}$ across, which contain ca. 35 wt.\% Ag, may occur in sphalerite. Abundant manganese minerals, goethite and covellite were found in weathered beresite.

The formation of auriferous mineralisation in beresites was connected with contact-metasomatic and hydrothermal processes of the KZS intrusion. Beresites were formed along the direct contact of Devonian quartz wackes with Visean tonalite as results of carbonatisation, silicification, sericitisation and sulphidisation of wackes (Mikulski, 1999b). Sulphide mineralisation hosted by beresites and different composition quartz veins precipitated during hydrothermal processes at medium to low range temperatures. The homogenisation temperatures of fluid inclusions of quartz veinlets hosting sulphides mineralisation indicate the crystallisation range of $210-280^{\circ} \mathrm{C}$ with the salinity of fluids corresponding to $3-7 \mathrm{wt} . \% \mathrm{NaCl}$ equivalent (Fig. 13 and Appendix 9). Recently, yellowish Sb-ochres, scorodite, cerusite, smithsonite, ferrihydrite, native sulphur and other minerals were also recognized in the weathered assemblages (Nejbert et al., 2013).

\section{PODZAMEK QUARRY}

The influence of high temperatures of the KZS pluton on its surroundings was also noted in the Podzamek region (Fig. 1). The temperatures of about $650^{\circ} \mathrm{C}$ have been fixed on the basis of wollastonite (Winkler, 1967) that was found in silicate-calcite rocks intimately associated with the contact. The rocks that built the granitoid complex in the Podzamek region are composed of granodiorite, monzonite and quartz monzonite with minor tonalite, syenite, monzogabro diorite and monzodiorite. However, the most interesting feature of the Podzamek area is the occurrence of different skarns and skarn-related rocks that associate with carbonate enclaves within the intimate metamorphic cover. They include: marbles, wollastonite marbles, vesuvianite marbles, marbles with garnet and pyroxene, garnet skarns, garnet-pyroxene skarns, garnet-feldspar-pyroxene-amphibole skarn (Juskowiak, 1959; Speczik, 1994).

\section{METAMORPHIC ROOF BLANKETS PATCHY DISTRIBUTED} ON THE KZS PLUTON

MĄKOLNO PROSPECT AND OTHER NEARBY LOCATIONS

Metamorphic rocks in Mąkolno represent a relict of the metasedimentary cover resting on the top of KZS pluton (Fig. 1). Ore mineralisation was found within a lens of limestone as well as in associated amphibolites. The mineralisation in amphibolites is similar to the first-stage mineralisation of Lutynka, and is 

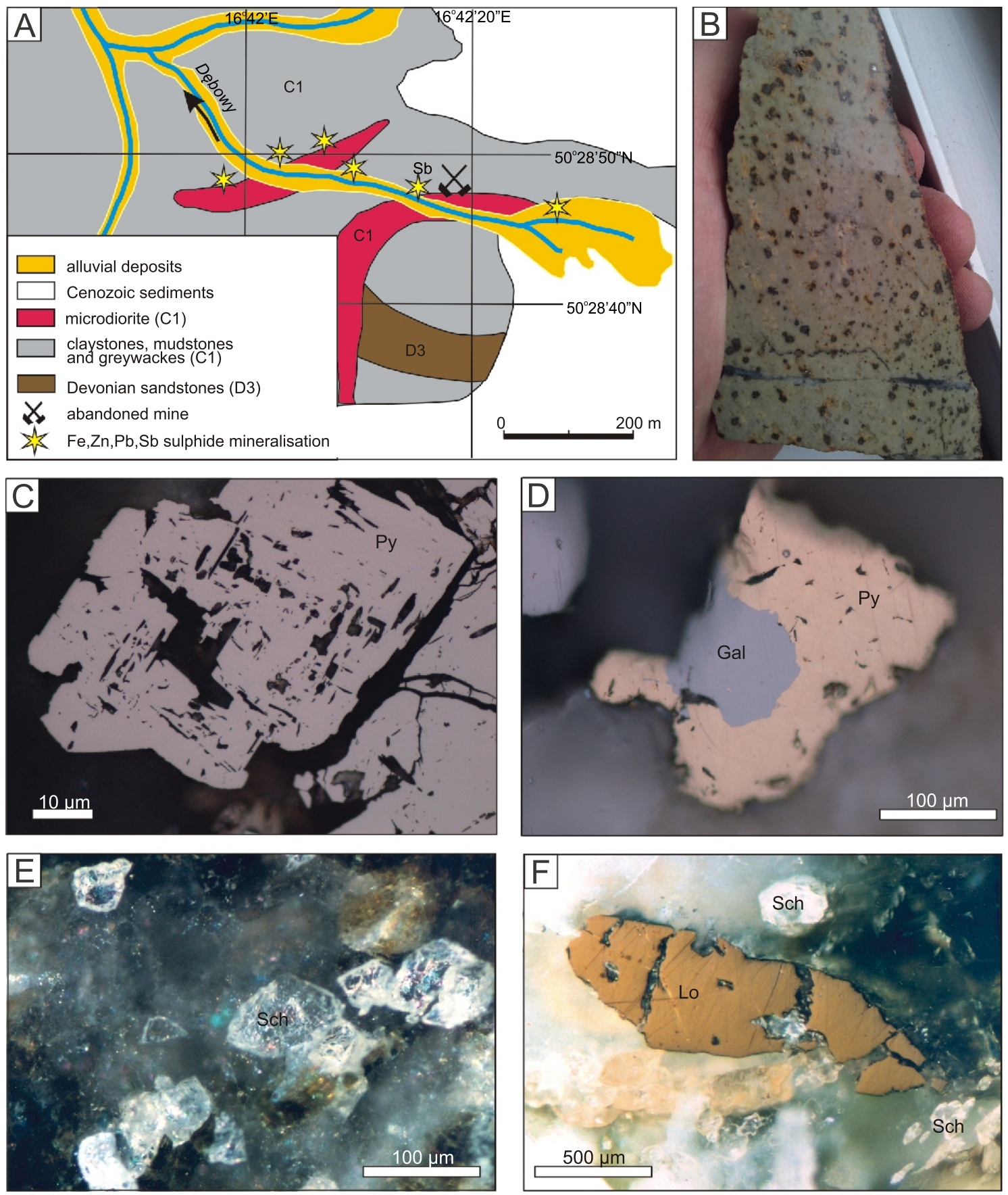

Fig. 12A - beresite occurrence from Dębowinka in the schematic geological map of Emerle-Tubielewicz (1979, modified); B - photograph of beresite rock with pyrite mineralisation from the Dębowinka prospect; C - euhedral pyrite (Py) crystal; D - intergrowths of galena (Gal) and pyrite (Py); E, F - the Mąkolno prospect: E - schelite (Sch) crystals under ore microscope, semi-crossed nicols, F - fractured löllingite (Lo) associated with scheelite (Sch) in strongly silicified amphibolitic hornfels

Photo $\mathrm{C}-\mathrm{F}$ in reflected light

credibly related to pre-Variscan regional metamorphism. Mineralisation in limestones is represented mostly by azurite, malachite, covellite and limonite. However, relicts of primary ore minerals, i.e. bornite with chalcopyrite intergrowths and chalcopyrite, were also found. Moreover, also gold in this area was found in two outcrops of amphibolites. Gold was determined (ca. 6 ppm) in weathered copper ores collected at the known old prospect in Mąkolno (Lis and Sylwestrzak, 1986; Muszer, 1992). Moreover, a new gold site was found about $1 \mathrm{~km} \mathrm{SW}$ of the old prospect near the ruins of a chapel. Gold (up to $5 \mathrm{ppm}$ ) occurs here in association with sulphides that form veinlet-impregnations within strongly altered amphibolites. Older-generation ore minerals are represented by abundant scheelite, titanite and löllingite (Fig. 12E, F) which are cataclassed and overprinted by auriferous arsenopyrite, pyrite and rare electrum micrograins and inclusions. Genesis of the ore mineralisation is strongly associated with contact metasomatic and hydrothermal processes developed between the granite and metamorphic cover rocks. Schee- 


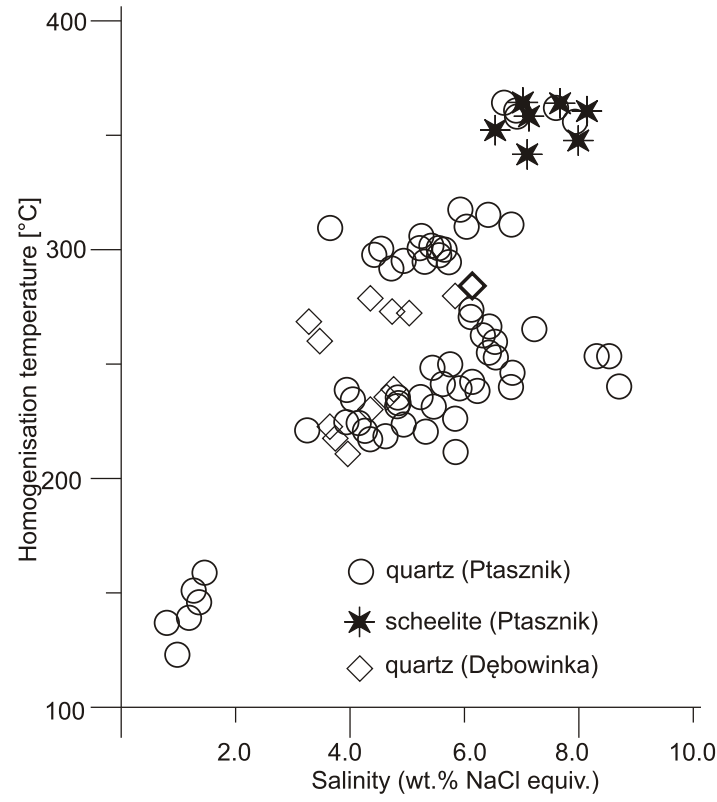

Fig. 13. Plot of homogenisation temperature versus salinity for primary fluid inclusions in quartz and scheelite from the Ptasznik and Dębowinka prospects

lite and titanite in association with löllingite, quartz and pyroxene in augite-hornblede rocks were the first to be formed at a high temperature (ca. $500^{\circ} \mathrm{C}$ ). Cataclassis of löllingite and scheelite indicates that the second stage of ore crystallisation was strongly associated with basification and silicification of amphibolites. As the result, hornblende formed, accompanied by quartz and arsenopyrite that replaced löllingite. According to the arsenopyrite geothermometer the arsenopyrite crystallisation took place at the temperature range from 410 to $480^{\circ} \mathrm{C}$ (Fig. 5 and Appendix 1). Arsenopyrite skeletal aggregates fill the intergranular spaces and are overgrown on coarse-grained quartz containing scheelite or löllingite. Pyrite appears as single grains up to $0.5 \mathrm{~mm}$ in size. Gold micrograins occur in association with calcite and younger-generation quartz in fractured arsenopyrite.

Moreover, in Chwalisław, in the northern part of the KZS the quartz veins with scheelite and Au traces have also been found (Fig. 1). These veins cut granodiorites and metamorphic rocks (mainly amphibolites and pyroxene gneisses). Quartz veins contain here minor ore minerals such as: scheelite, arsenopyrite, pyrite, titanite, rutile and very fine single crystals of molybdenite. These quartz veins contain traces of gold $(<0.1 \mathrm{ppm})$

PTASZNIK Ti-W-AU PROSPECT

Tungsten-titanium mineralisation of metasomatic type associated with hydrothermal Au-bearing quartz-K feldspar stockworks and veins were encountered in the Ptasznik metamorphic cover about $5 \mathrm{~km}$ SW from the Złoty Stok Au-As deposit (Fig. 1). Epigenetic ore mineralisation is represented here by scheelite and titanite with smaller amounts of sulphides and traces of gold. It was possible to identify primary mineralisation due to heavy mineral prospecting of alluvials (Mikulski, 2000). Coarse grains of scheelite $(>1.0 \mathrm{~mm}$ in size) with characteristic sharp edges were found only near the outcrops of the primary tungsten mineralisation (Mikulski and Wierchowiec, 2013). The roof of KZS is formed by irregularly distributed relics of Lower Paleozoic metamorphosed volcanic and sedimentary rocks corresponding to the Śnieżnik Metamorphic rock unit that surrounds the intrusion on the east. The sedimentary rocks enclose mafic and felsic intercalations regionally metamorphosed at the amphibolite facies and then affected by contact metamorphism of the granite intrusion. The Ptasznik roof cover is built of pyroxene amphibolites, amphibolic schists, pyroxene-plagioclase rocks, gneisses and cordierite hornfelses injected by porphyritic granodiorite dykes and subsequently intersected by melanocratic and leucocratic dykes and quartz veins (Fig. 14). It was later fragmented into smaller pieces which were uplifted and shifted along regional shear zones of the NNW direction. The youngest deformation, resulting in a number of cataclasites, mylonites and breccias, enabled hydrothermal solutions to infiltrate the intrusion and the country rocks. Scheelite mineralisation occurs in the form of impregnation in a quartz K-feldspar stockwork, veins and breccias intersecting the amphibolite and/or gneiss schistosity (Fig. 15A-D). This mineralisation fills the NNW fractures $\left(165-10^{\circ}\right)$ dipping steeply to the $E$ or W $\left(80-90^{\circ}\right)$. In the granite, only traces of Mo-scheelite mineralisation were found.

Chemical analyses determined $18.4 \mathrm{ppm}$ Au and $0.3 \mathrm{wt} . \%$ $\mathrm{WO}_{3}$ at the maximum. The mean gold content is $53 \mathrm{ppb}$ $(n=75)$. High Au concentrations (5-9 ppm) were found in several samples of quartz veinlets intersecting altered metamor-

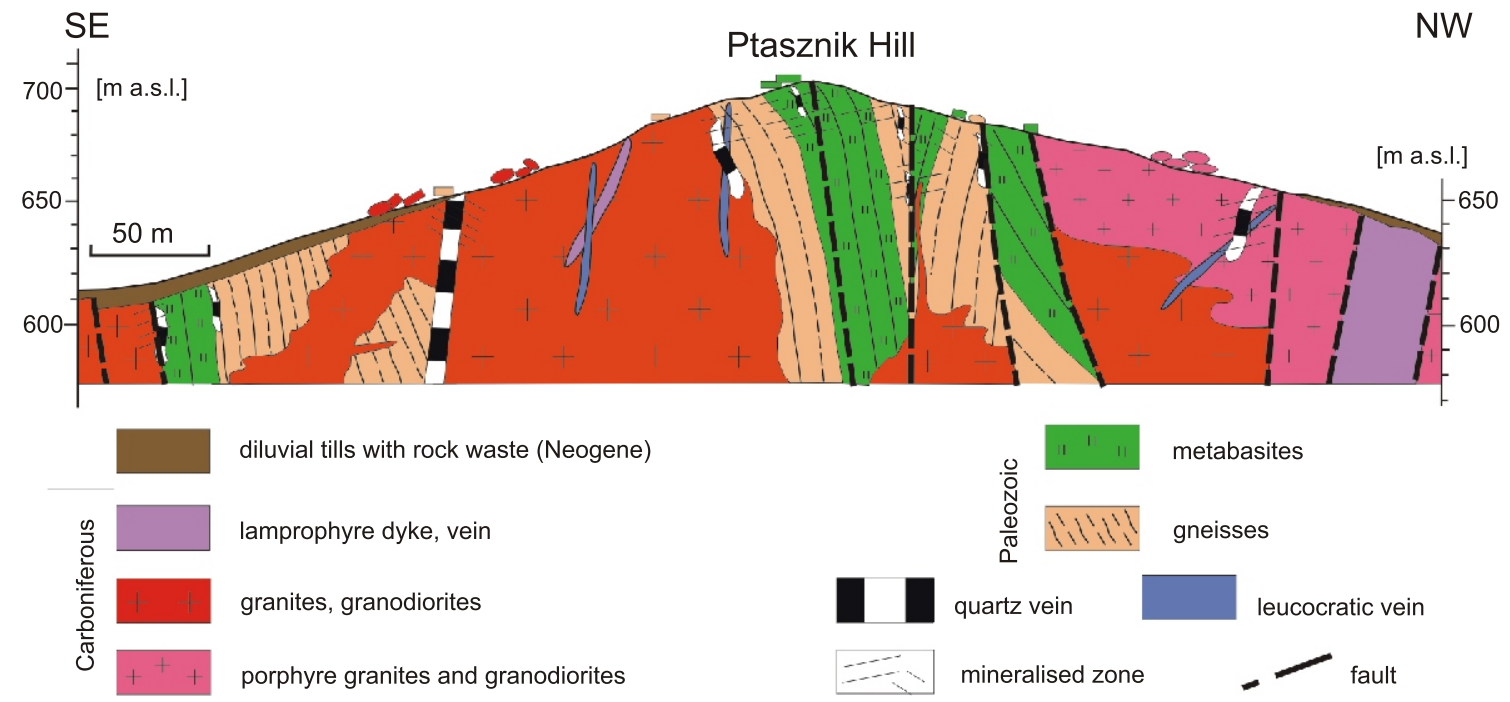

Fig. 14. Geological cross-section of the Ptasznik Hill prospect with Ti-W mineralisation (modified after Mikulski, 2000) 

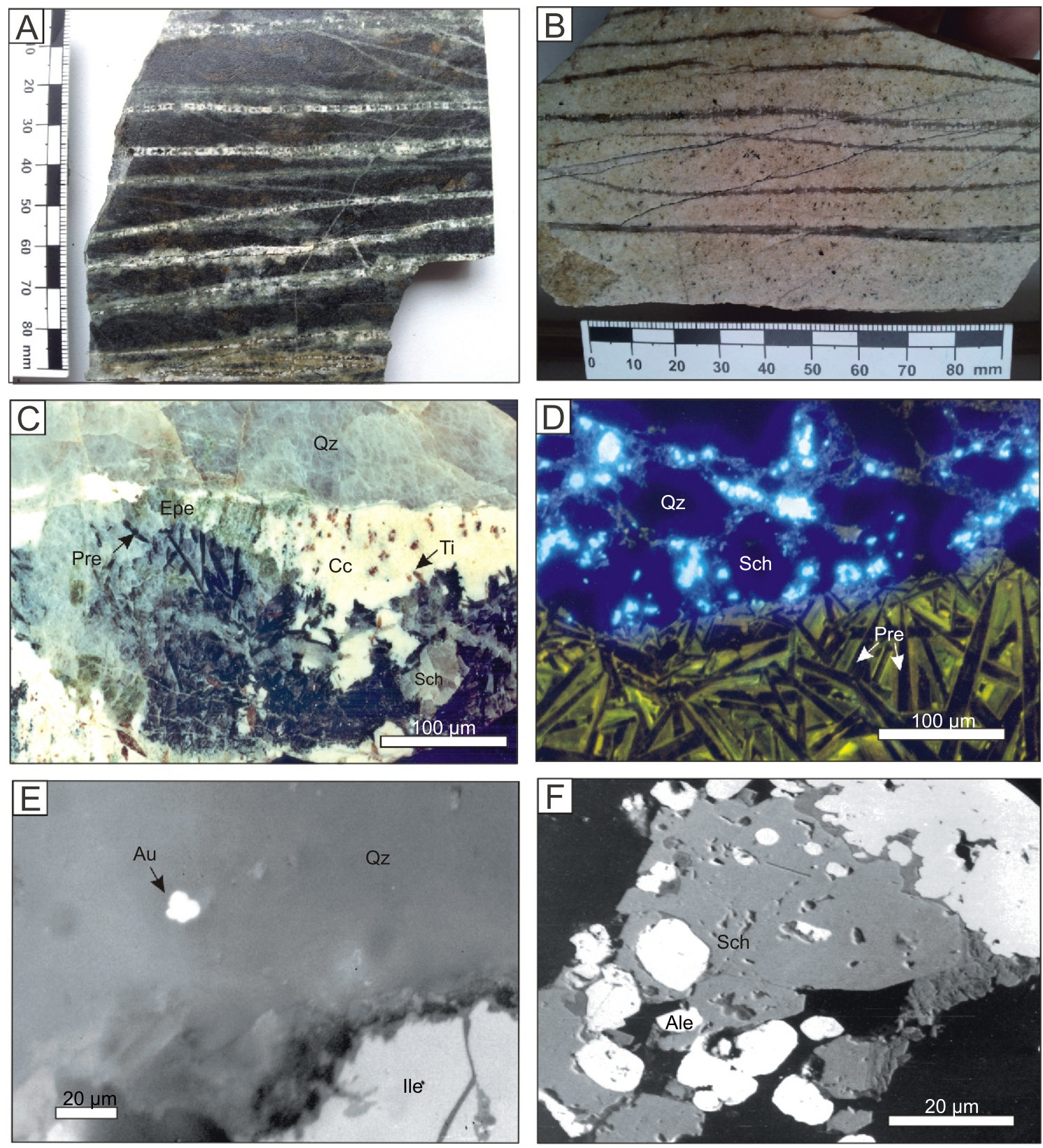

Fig. 15. Photographs of typical stockworks of quartz-feldspar (K)-carbonate veinlets with scheelite-titanite mineralization hosted by pyroxene amphibolite (A) and gneiss (B); C - photograph of quartz-feldspar (K)-carbonate-epidote veins with idiomorphic crystals of augite with columnar habit (black), titanite rhomboids (brown), and scheelite mineralisation; D - microphotograph in cathodoluminescence light with quartz, scheelite and prehnite; E - gold micrograin in quartz veinlet, photo in reflected light; $\mathbf{F}$ - scheelite replacement by minerals from the allanite group, note visible dark grey transit zone with allanite enriched in Cerium, backscattered electron image

Ale - allanite, Au - gold, Epe - epidote, Ile - ilmenite, Pre - prehnite, Qz - quartz, Ti - titanite, other explanations as in Figure 3 and 4

phic rocks (Fig. 16 and Appendix 10). Amphibolite hosting quartz stockworks with scheelite contains an average of $1.42 \mathrm{ppm} \mathrm{Au}(n=13)$, gneisses with quartz veinlets only $3 \mathrm{ppb}$ $\mathrm{Au}(n=6)$, and quartz veins with scheelite - $1.24 \mathrm{ppm} \mathrm{Au}$ $(n=16)$. However, analyses indicate an uneven Au distribution in scheelite-bearing rocks due to an irregular occurrence of gold in quartz-K feldspar veins and silicified rocks. In the quartz veinlets, gold forms flat and elongated grains $5-30 \mu \mathrm{m}$ in size and may contain up to $15 \mathrm{wt} . \% \mathrm{Ag}$. In granitised amphibolites, rare gold grains in association with ilmenite, scheelite and titanite may be up to $50-100 \mu \mathrm{m}$ in size (Fig. 15E). Electrum was found in the form of ca. 5-10 $\mu \mathrm{m}$ inclusions in arsenopyrite or as grains in cataclastic fissures in löllingite-arsenopyrite aggregates. Genesis of the gold and scheelite mineralisation is inter- 


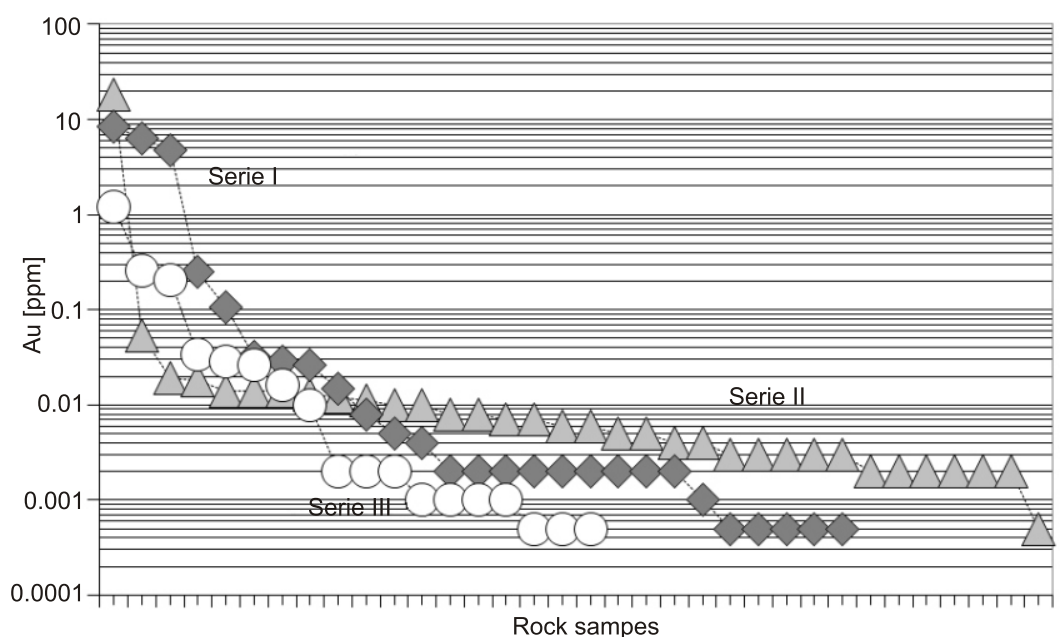

Fig. 16. Logarithmic plot of gold concentration in quartz veins and scheelite-bearing rocks from the Złote Mountains; Serie I - scheelite-bearing quartz veins, quartz-feldspar (K) rocks, and leucocratic veins from the Ptasznik prospect (rhombohedrons); Serie II - alterered metabasite hornfelses from the Ptasznik prospect (triangles); Serie III - quartz veins from the Złote Mts., beyond the Ptasznik prospect (circles)

preted as postmagmatic, related to hydrothermal processes when granitoids were affected by cataclasis ca. $333 \mathrm{Ma}$ (Mikulski et al., 2013).

Kłodzko-Złoty Stok granite is a type I oxidized acid intrusion owing to oxidising hydrothermal fluids which were capable of transporting gold and, possibly, were also the source of gold to some extent. Tectonic structures (faults and shears) provide a 'plumbing system' for Au-bearing fluids. Scheelite and titanite mineralisation is strongly associated with the presence of mafic rocks which were subjected to late fracturing and strong alteration. The most abundant scheelite mineralisation occurs in the areas characterized by the presence of melanocratic and leucocratic dykes. Geological thermometers indicate contact metamorphism of pyroxene-hornfels facies in the Ptasznik metamorphic cover $\left(660-710^{\circ} \mathrm{C}\right.$ and about $3 \mathrm{~kb}$; Bagiński, 2007). Biotitisation and pyroxenisation were followed by K-feldspar metasomatism and silicification accompanied the main stage of ore mineralisation represented by scheelite and titanite with a small amount of sulphides and traces of gold. Abundant scheelite-titanite mineralisation is present in zones of strong silicification and K-feldspar metasomatism at the temperature of about $460^{\circ} \mathrm{C}$. The results of fluid inclusion studies of scheelite and quartz from strongly metasomatically altered pyroxene amphibolites indicate the crystallisation range of $440-460^{\circ} \mathrm{C}$ and $1.2 \mathrm{~kb}$ pressure with the salinity of fluids corresponding to 7-11 wt.\% NaCl equivalent (Mikulski and Kozlowski, 2001). The crystallisation of $\mathrm{Ti}$ minerals and scheelite preceded $\mathrm{Au}$ mineralisation associated with younger generations of quartz veinlets and sulphides, which were formed at the temperature $<300^{\circ} \mathrm{C}$. In the subsequent alteration stages, chloritisation of mafic minerals and crystallisation of sulphides occurred, accompanied by sericitisation and albitisation of plagioclase. Epigenetic sulphides are represented mainly by pyrite and arsenopyrite, to a lesser degree by chalcopyrite and pyrrhotite and rare free gold grains and gold inclusions hosted by arsenopyrite. Weak scheelite mineralisation of a younger stage is accompanied by calcite, prehnite, epidotes and pyrite, which form veinlets representing the late products of mafic rocks alteration. Scheelite is also replaced by $\mathrm{Ce}$ - and La-bearing allanites that indicate REE-rich hydrothermal fluids (Fig. 15F).

\section{THE CENTRAL AND SOUTHERN PARTS OF THE KZS PLUTON}

\section{JASZKOWA GÓRNA PROSPECTS}

Scheelite mineralisation with traces of gold $(<0.2 \mathrm{ppm})$ in two quartz veins and quartz boulders were found in the SE parts of the KZS and within its contact with metamorphic rocks of the Stronie series in the vicinities of Jaszkowa Górna (Fig. 1). The first quartz vein $(170 / 75 \mathrm{E})$, about $5 \mathrm{~cm}$ thick, cuts porphyre granodiorites and fine-grained granite and is composed of grey-white coarse-grained quartz with scheelite, anhedral pyrite and rare chalcopyrite grains. In quartz druses, common micro-veinlets of Fe-hydroxides were noted. The second quartz vein (30/70 E), about $1 \mathrm{~m}$ thick, cuts strongly granitised and silicified amphibolites that outcrop south-west of the first quartz vein.

\section{ŻELAZNO}

In the Żelazno area (southwestern aureole) it is possible to observe the intimate contact between the KZS and its metamorphic cover in several quarries. Here, the thermal and metasomatic influence of granitoids on its metamorphic cover is expressed profoundly even with symptoms of extensive granitisation (Wierzchołowski, 1976). Good examples of contact-metasomatic ores of different types and compositions are found in two quarries. The first one is situated near the state road Lądek Zdrój-Kłodzko and the second one is located in the village of Dolne Żelazno. Both amphibolite and amphibole gneiss quarries represent rather joint series in which one or the other rock type dominates. In comparison with amphibole-gneisses the amphibolites are enriched in dark minerals and are fine-grained. Silicate-calcite rocks in the quarry often contain elongated inclusions of pyroxene plagioclase hornfelses. Gneisses that occur in the lowermost part of the Stare Żelazno profile are finely laminated dark grey rocks composed of parallel-arranged crystals of plagioclase, biotite, amphibole, and minor quartz. They reveal both symptoms of mechanical destruction and metasomatic recrystallisation. Amphibole is represented mainly by antophylite, actinolite and minor green hornblende. Accessory minerals are zircons, apatite and Ti-Fe oxides. 


\section{ORE CRYSTALLISATION SEQUENCE}

In general, the paragenetic sequence of ore mineral crystallisation in rocks from the contact aureole of the Kłodzko-Złoty Stok intrusion is as follows:

- metamorphosed sulphide and oxide minerals;

- contact metasomatic ore mineralisation (e.g., skarns, metasomatic replacement ore bodies, beresites and veinlets-impregnations with oxide, and auriferous sulphide minerals);

- quartz-K-feldspar veins locally with minor sulphides and traces of gold;

- quartz-silicate-carbonate green serpentinite veinlets with ore minerals.

The overall ore-mineralisation stages are developed within a transition from ductile-brittle to brittle condition by hydrothermal circulation and accumulation of ores. The regional metamorphism and the subsequent dynamic metamorphism (strong mylonitisation) related to the emplacement of the KZS pluton and the development of the Złoty Stok-Skrzynka Shear Zone constitute a frame of reference for the late-stage cataclasis of ores according to the brittle deformational effects. Therefore, the significant differences between the contents of ore minerals in different zones around the KZS pluton should be also noted. Variable alteration processes: hornfelsitisation, skarnisation, dolomitisation, serpentinisation, biotitisation, pyroxenisation, K-feldspatisation, silicification, berezitisation, carbonatisation, prehnitisation, chloritisation, epidotisation and sulphidisation developed in relation to different types of country rocks of the KZS pluton. The contact-metasomatic mineralisation of Au-As-Fe skarn-like type at the Złoty Stok deposit and Bardo Ślaskie prospect, as well as the scheelite-titanite mineralisation in the Ptasznik roof pendant of the KZS and beresite mineralisations from Dębowinka are interpreted as postmagmatic, related to hydrothermal processes in the Mississippian. The beresite mineralisation formed when granitoids were locally affected by cataclasis.

At the Złoty Stok, extensive contact metasomatic alteration started with skarnisation of carbonate rocks and serpentinisation of ultramafic and mafic rocks. Ore mineralisation formed lenses variable in size in the Stronie metamorphic rock series. The crystallisation sequence of the ore minerals resulted from different types of metasomatic fluid fronts associated with the granodiorite intrusion. The fluids of magmatic origin transformed primary calcareous rocks into a calc-silicate and pyroxene-garnet skarn-like sequence. In carbonate rocks, transformation started with dolomitisation and pyroxenisation followed by ore mineralisation. The metasomatic processes may be divided into: a calcsilicate sub-stage with pyroxene (diopside), garnet, quartz and calcite, associated with oxide \pm sulphide ore mineralisation (magnetite, pyrrhotite, scheelite, powellite, titanite), followed by a sulphide sub-stage with pyrrhotite, löllingite, arsenopyrite, pyrite and "invisible gold" (Fig. 17). Arsenopyrite is generally younger than löllingite, which together with commonly oriented intergrowths of chalcopyrite in pyrrhotite may suggest high $\left(>550^{\circ} \mathrm{C}\right)$ temperatures of metasomatic processes during the formation of pyrrhotite-associated minerals.

The calcsillicate sub-stage is characterized by crystallisation of skarn-like mineral assemblages represented by pyroxene, garnet and scheelite. Magnetite-rich mineralisation in dolomitic marbles is characterized by increased amounts of organic material, while in samples with rich arsenic ore the content of organic matter is lower (Mikulski and Speczik, 2008).

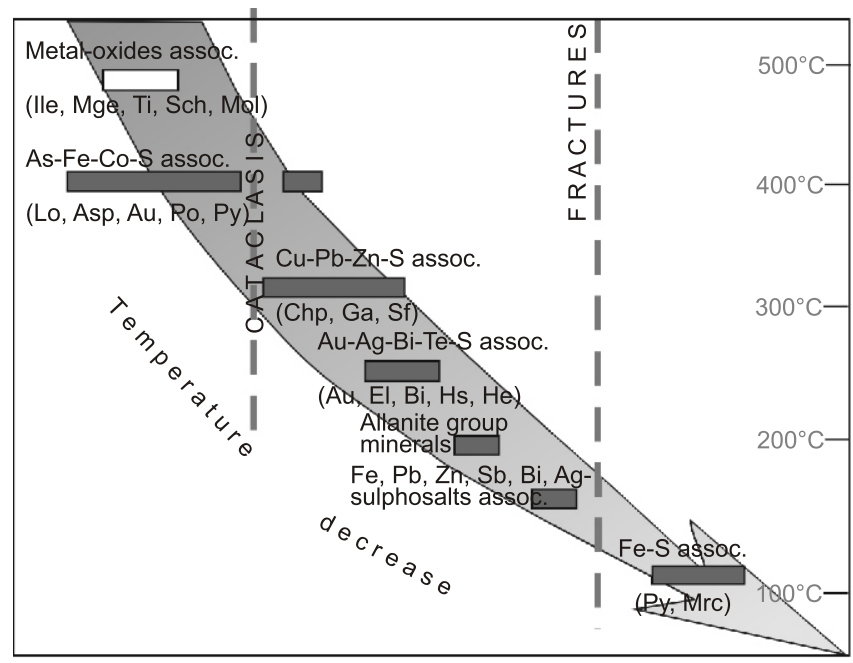

Fig. 17. The schematic succession of ore minerals formed during the post-magmatic hydrothermal activities related to the Kłodzko-Złoty Stok Pluton

Chp - chalcopyrite, $\mathrm{Ga}$ - galena, $\mathrm{He}$ - hedleyite, $\mathrm{Hs}$ - hessite, $\mathrm{Mol}$ - molybdenite, Mrc - marcasite, Sf - sphalerite, other explanations as in Figures 3 and 4

Fluid inclusion studies of these minerals demonstrate that the earliest stage was characterized by saline fluids (4.9-5.2 wt.\% $\mathrm{NaCl}$ equiv.) with homogenisation temperatures from 464 to $480^{\circ} \mathrm{C}$, which were trapped at pressures above $1.4 \mathrm{~kb}$ (Mikulski, 1996a). A similar range of temperatures $\left(440-460^{\circ} \mathrm{C}\right.$ and $1.2 \mathrm{~kb}$ pressure with fluids salinity corresponding to $7-11 \mathrm{wt} . \% \mathrm{NaCl}$ equivalent) was revealed by fluid inclusion studies of scheelite and quartz from strongly metasomatically altered pyroxene amphibolites from the Ptasznik Hill (Mikulski, 2001). The K-feldspar-titanite-scheelite assemblage occurs in metasomatically replaced rocks and veins. The scheelite-prehnite-calcite association occurs within metasomatically altered mafic rocks and late fracturing stages. The metasomatic scheelite crystallised at the same time as the scheelite in the veins and stockwork at the temperature of $440-460^{\circ} \mathrm{C}$. The most abundant scheelite mineralisation occurs in the areas characterized by the presence of melanocratic and leucocratic dykes.

Geological thermometers indicate contact metamorphism of pyroxene-hornfels facies in the Ptasznik roof pendant $\left(660-710^{\circ} \mathrm{C}\right.$ and about $\left.3 \mathrm{~kb}\right)$. In pyroxene amphibolites enclosing scheelite mineralisation, coarse-grained pyroxene (up to 9.4 wt.\% MgO) and biotite (ca 1.9 wt.\% MgO) occur. Biotitisation and pyroxenisation was followed by K-feldspar metasomatism and silicification accompanied by titanite and scheelite crystallisation (Mikulski, 2000). Remobilization and redeposition of $\mathrm{W}$ is marked by scheelite \pm prehnite \pm calcite veinlets or insignificant scheelite fissure fillings that resulted from alteration of ultramafic and mafic rocks. In places, scheelite was replaced by allanite. In the subsequent alteration stages, chloritisation of mafic minerals and crystallisation of sulphides occurred, accompanied by sericitisation and albitisation of plagioclases.

Au mineralisation associated with the second and third generations of quartz veins with sulphides is posterior to the origin of $\mathrm{Ti}$ and $\mathrm{W}$ mineralisation.

The latest stage is represented by quartz, quartz-calcite, carbonate and/or green serpentine veinlets containing also ore minerals such as arsenopyrite, pyrite, chalcopyrite or scheelite, 
and locally with minor pyrrhotite, sphalerite or native gold. This stage is marked by an increased content of barren calcite or calcite enriched in sulphoarsenides and inclusions of native gold. Among ore minerals the main role is played by pyrite or marcasite, Co-gersdorffite, Ni-cobaltite, native gold, native bismuth, electrum, maldonite, bismuthinite and galena.

\section{INTERPRETATION OF DATA - METALLOGENIC EVOLUTION OF KZS PLUTON AND ITS AUREOLE}

Two major periods of mineralisation were found in the investigated metamorphic rocks of the Złoty Stok-Skrzynka regiona Shear Zone. The first period is related to pre-Variscan regional metamorphism of volcanic-sedimentary pile that was at places enriched in $\mathrm{Fe}, \mathrm{Ti}, \mathrm{Ni}$, and $\mathrm{Cu}$. This mineralisation type occurs in country rocks of the Złoty Stok deposit, salbands of the Lutynka $\mathrm{Pb}-\mathrm{Zn}$ deposit and metabasites of other locations, with Fe-Ti oxides generally dominating over $\mathrm{Fe}-\mathrm{Cu}-\mathrm{Ni}$ sulphides. The second period, the more important, is related to a thermal and metasomatic influence of the Kłodzko-Złoty Stok Granite Pluton. Some pegmatitic dikes and veins with rich löllingite/arsenopyrite mineralisation (Złoty Jar, Jaszkowa Góra) are probably heralding skarn-type and metasomatic-hydrothermal forms of mineralisation. Fluids related to granitoids migrated preferentially along tectonic fractures and affected strongly rocks that were highly susceptible to metasomatosis, i.e. dolomitic marbles, amphibolite and brecciated rocks. The critical process for the formation of rich arsenide ore was serpentinisation of dolomitic marbles accompanied by the formation of several varieties of calc-silicate skarn-type rocks. These processes produced a profound vertical and horizontal mineral and metal zonation with respect to the position of Kłodzko-Złoty Stok granitoids (Fig. 18).

In the Złoty Stok deposit the Western Ore Field is dominated by löllingite mineralisation rich in Au, associated with diopside-tremolite-garnet skarns. The amount of löllingite and Au as well as the intensity of serpentinisation processes decrease eastward, but the amount of $\mathrm{Cu}, \mathrm{Pb}$ and $\mathrm{Zn}$ minerals increases. Arsenopyrite mineralisation (rich in Co, up to $\sim 4$ wt.\%) found in salbands of Lutynka $\mathrm{Pb}-\mathrm{Zn}$ deposit shows similarities to arsenide mineralisation found in country rocks of the Złoty Stok deposit and provides an important link between both mineralisations (Speczik, 1994). Besides, considering the long horizontal distance (ca. $3 \mathrm{~km}$ ) from the Lutynka and granitoid outcrops, the Lutynka ores may be interpreted as a farther $\mathrm{Pb}-\mathrm{Zn}$ manifestation of the same metallogenic process (Olszyński and Speczik, 1993). This may be also suggested with respect to Mąkolno, where the granitoid-capping limestones are enriched in Cu minerals. Moreover, amphibolite and amphibolic schists (but over a limited distance) are also strongly altered in this area. They contain relics of oxide-sulphide mineral assemblages of primary magmatic origin, metamorphosed in amphibolite facies. In altered amphibolites, ilmenite is replaced by titanite, rutile and leucoxene, pyrrhotite by pyrite, löllingite by arsenopyrite, and Fe spinels by sulphides. A new generation of ore minerals of scheelite, titanite, and $\mathrm{Fe}-$ and $\mathrm{Cu}$-sulphides with traces of gold was also formed. W-Ti mineral assemblages were discovered in the Ptasznik roof cover, which was in many places intruded by porphyritic granodiorite dykes and subsequently intersected by melanocratic and leucocratic dykes and post-magmatic quartz veins of various strikes. Leucogranite dykes indicate more fractionated granites. It was further fragmented into smaller pieces which were uplifted and shifted along regional shear zones of NNW direction. The youngest deformation resulting in a number of cataclasites, mylonites and breccias enabled hydrothermal solutions to infiltrate the intrusion and the country rocks. Scheelite-titanite mineralisation of veinlet-impregnation type originated in zones of strong silicification and K-feldspar metasomatism at the temperature of about $460^{\circ} \mathrm{C}$. W-Ti mineralisation preceded Au and As- and Fe-sulphide-bearing quartz mineralisation. The finding of tungsten-titanite and arsenide mineralisation in amphibolites of the SE Kłodzko-Złoty Stok granitoid contact may suggest extensive and regional mineralisation. Moreover, along the NW contact aureole of the KZS
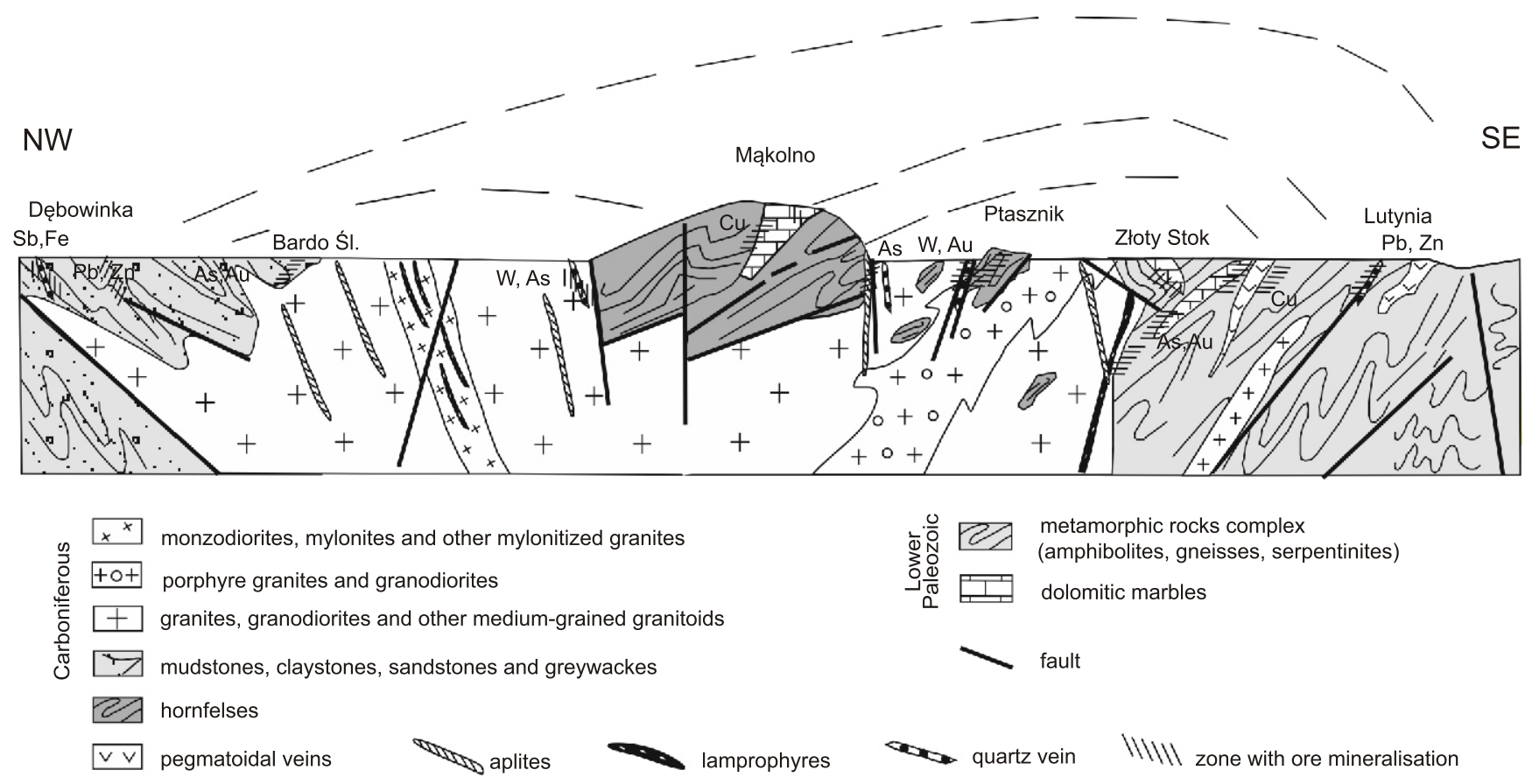

Fig. 18. The zonation distribution of ore mineralisation around the Kłodzko-Złoty Stok intrusion 
pluton with the Bardo Structure in the Bardo Śląskie and Dębowinka prospects, there is auriferous sulphide mineralisation hosted by Upper Devonian-Mississippian sedimentary rocks. These rocks underwent strong hornfelsisation along the contact with granitoids. In Bardo Ślaskie the contact-metasomatic auriferous arsenopyrite and pyrite mineralisation is associated with strong alteration of country rocks (K-feldspatisation, silicification, carbonatisation, sericitisation). In Dębowinka, beresites with auriferous pyrite mineralisation of veinlet-impregnation type were formed as a result of post-magmatic activities. These findings of auriferous ore mineralisation along the northwestern contact of KZS, with slightly metamophosed sedimentary rocks from the Bardo Mts., indicate that the whole KZS is ferritile in gold.

\section{DISCUSSION AND CONCLUSIONS}

The Kłodzko-Złoty Stok intrusion and its metamorphic rock cover are unique examples of various types of ore mineralisation distribution around the I-type Variscan granitoids, which survived due to a low level of erosion. The patchily distributed remnants of the primary metamorphic cover contain variable types of ore mineralisation that, in many cases, reflect differences in rock compositions and the degree of contact metamorphic alteration. Variation in ore mineral compositions was recognized in numerous outcrops distributed across the whole KZS pluton. Moreover, ore mineralisation found throughout the KZS pluton and its country rocks indicates a specific zonal distribution that reflects a different interaction between postmagmatic mineralising fluids and variable country rocks. This especially concerns different types of auriferous mineralisation recognized in the KZS pluton and its aureole.

The metamorphic cover, despite differences such as rock compositions, ages, degree of metamorphism and tectonics, hosts variable ore mineralisation that reflects a spatial position relative to the core of KZS granitoids. The presence of lamprophyres also gives direct evidence as to the nature of the mantle sources of the KZS magmatic system. It also provides a clear evidence for the mantle source of the thermal input into the evolving granitoid magma reservoir, partly accounting for the high temperatures, up to $750^{\circ} \mathrm{C}$, recorded in contact metamorphic rocks in the roof zone of the KZS pluton (Bagiński, 2007). Due to subsequent magmatic and postmagmatic activities, first high-temperature and then medium- and low-temperature ore mineralisation developed practically around the whole KZS pluton. The shift from mesothermal to epithermal gold mineralisation in quartz-lode type deposits of the European Variscan belt is recognized as a common feature, driven by changes in the uplift rates, tectonic regimes and heat production (Cathelineau et al., 2003). Those authors recognized that several Pennsylvanian orogenic gold deposits show identical patterns of P-T-X-t fluid evolution that strongly differ from the commonly accepted models for orogenic Au deposits, allowing the definition of a Variscan-type of gold deposits. According to Noronha et al. (2000), gold ores in northern Portugal appear as the result of successive fluid circulation stages during the Variscan orogeny. Deeply penetrating water in the uplifting basement was driven up by heat flow linked to the late granite intrusions. Gold was remobilized from metamorphic series and deposited in structural and geochemical traps. Gold deposition was related to progressive dilution and cooling of the crustal fluids by oxidising solutions penetrating the basement from the surface. The changeable ways of magmas fractionation, degree of compositional evolution and further tectonic processes may produce different types of ore mineralisation that reflected transition from magmatic to hydrothermal environments. $\mathrm{Cu}$ and $\mathrm{Au}$ deposits are related to more mafic granites. Tungsten mineralisation is correlated with granitic magmas of transitional character and Mo-W-Sn with felsic and fractionated granite (Blevin and Chappell, 1995). Oxidation state of magmas is of paramount importance in controlling the nature of many ore elements, and it allowed dividing the granites into two contrasting granite types (Chappell and White, 1974, 2001; Frost and Frost, 2011) and further into the ilmenite and magnetite series (Ishihara, 1981). Cu, Mo and Au deposits are typically related to magnetite-bearing (oxidized) granite, while $\mathrm{Sn}( \pm \mathrm{W})$ deposits to ilmenite-bearing (reduced) granite. The oxidation state of the igneous system is suggested to control the process of hydrothermal redistribution (Lehmann, 1994). The KZS pluton is built mostly of calc-alkaline and metaluminous granites with some transition to peraluminous granites (Fig. 19 and Appendix 11). The position of the KZS granite samples on the diagram of the K/Rb ratio versus silica contents (Fig. 20 and Appendix 12) indicates that the granites are moderately evolved. According to Chappell (2003) the K/Rb ratio versus silica contents is very useful in defining strongly fractionated granites, the most characteristic for cassiterite and wolframite mineralisation. KZS granites are moderately evolved and they lack of this type mineralisation.

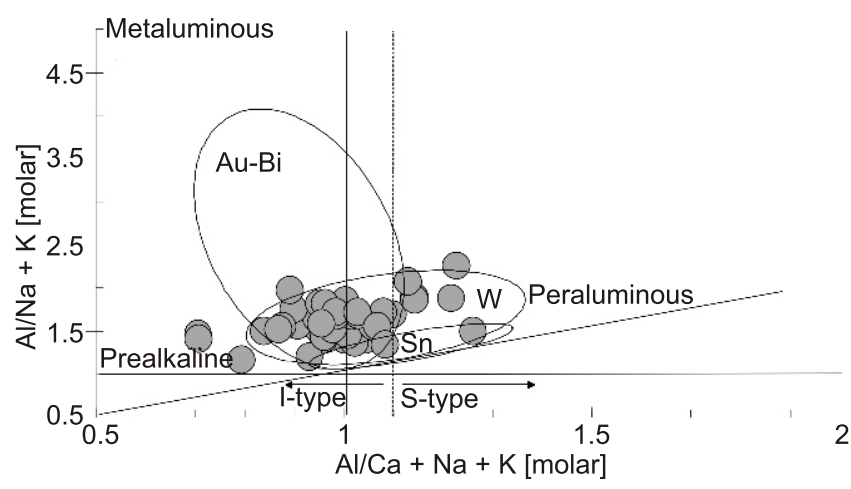

Fig. 19. A/NK versus $A / C N K$ classification after Maniar and Piccoli (1989) of granitoid samples from the Kłodzko-Złoty Stok Granite Pluton according to data presented by Mikulski et al. (2013)

Abbreviation of ellipsoids after Baker et al. (2005): Au-Bi dominant granites, $\mathrm{W}$ - dominant granites, $\mathrm{Sn}$ - dominant granites

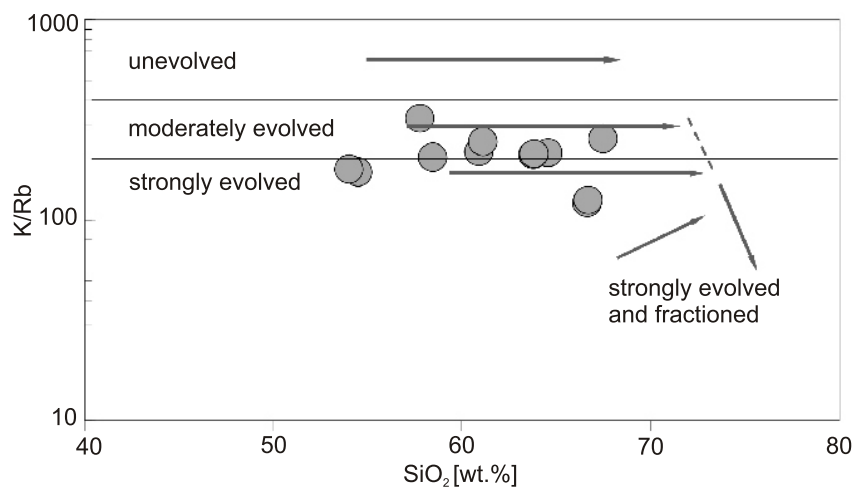

Fig. 20. Estimation of the degree of granite evolving and fractionation, Blevin's plot (2003) of $\mathrm{K} / \mathrm{Rb}$ vs. $\mathrm{SiO}_{2}$ applied for granitoids from the Kłodzko-Złoty Stok Granite Pluton 
Richer W mineralisation is known only from the Ptasznik Hill when the most fractionated granite occurs (Mikulski et al., 2013). Variation in the oxidation state may be consistent with a change in metallogeny from tin-rich to tungsten gold-rich systems (Thompson et al., 1999). Figure 19 clearly shows that the KZS granite samples are located mainly in the metaluminous and transitional to peraluminous fields. Microscopic studies of KZS granitoids indicate the presence of both magnetite and ilmenite in granite, suggesting a transition state of magma oxidation. The earliest granitoids are more mafic. It is a reason while, in the KZS pluton and in its sourroundings, various types of ore mineralisation (replacements ore bodies, skarns, breccias, disseminated and veins) were formed with numerous enrichments in gold of economic and indicatives values. KZS granites have intermediate or even low $\mathrm{SiO}_{2}$ contents, which is considered as preferential for $\mathrm{Cu}$ mineralisation (Blevin, 2003). In contrast, within the regions where granite with high silica contents appear preferably, Sn, Mo, U and Au deposits dominate. The Harker diagrams of KZS granites indicate the $\mathrm{SiO}_{2}$ concentration from 48 to $>70$ wt.\% (Mikulski et al., 2013). The $\mathrm{pH}$ evolution of the moderate- and low-temperature hydrothermal fluids into more oxidized is evidenced by the common occurrence of quartz and quartz-carbonate veins, which are widely distributed in the whole KZS pluton.

Chemical analyses of the granites from the KZS pluton as well as the position of samples on the Harker's diagrams suggest the intense development of the mixing and mingling process during magma intrusion. Locally, magma was more differentiated and enriched in volatile compounds, water and silica, which caused the formation of miarolitic pegmatite, aplite dyke and quartz vein. This magma was characterized by high potential for generation of post-magmatic fluids from which ore minerals precipitated. Mineral assemblages reveal predominance of pyrite, chalcopyrite and arsenopyrite over other metals. This is a characteristic feature of the I-type granite in which Mo-Cu \pm Au mineralisation more probably formed, especially where the high-temperature and oxidized granite occurs (magnetite series; Blevin 2003). However, only traces of molybdenite mineralisation have been found in the KZS pluton, probably due to the low silica content. The W-Ti mineralisation of veinlet-impregnation character from the Ptasznik prospect shows some similarity to the Au-bearing quartz veins associated with the Central Bohemian Plutonic Complex (Morávek et al., 1996; Zacharias et al., 2014) in the Czech Republic. However, in the case of KZS pluton the mineralisation was found within roof pendants mainly along the direct contact of small-size lenses of pyroxene-amphibolite and biotite-cordierite hornfels with granodiorites. Scheelite and titanite mineralisation occurs in hydrothermal quartz veins and stockworks formed at a temperature of $460^{\circ} \mathrm{C}$, in zones of strong silicification and K-feldspar metasomatism of the host rocks. Subsequent retrogression at a temperature $>320^{\circ} \mathrm{C}$ is marked by the presence of chlorite and sericite.

Post-magmatic activities in the KZS pluton are also in some places strongly related to tectonic processes, which resulted there in the occurrence of different types of ore mineralisation. Skarns and replacement ore-bodies occurred preferentially along the direct contact of the KZS pluton with carbonaceous rocks of the Stronie metamorphic rock series. The most variable composition of ore minerals are found in the Złoty Stok deposits located along the eastern margin of the KZS pluton in the shear zones of the Złoty Stok-Skrzynka and along the marginal Sudetic fault near the northwestern margin of Bardo Śląskie. Ore minerals are represented here by magnetite-pyrrhotite and löllingite-arsenopyrite-pyrite skarns, and chalcopyrite, and rarely by sphalerite, galena and native bismuth. Base-metal suphides appear in quartz and quartz-carbonate veinlets filling variably oriented fractures (Mikulski, 1996a, b). In other locations outwards from the KZS pluton (e.g. Lutynka, Dębowinka) the ore mineralisation (pyrite, galena, sphalerite, chalcopyrite, bismuth minerals, stibnite, titanite and hematite) was found in quartz veins and veinlet impregnation (Olszyński and Speczik, 1993; Mikulski, 1999b).

Around the core of the KZS pluton the following zones of ore mineralisation can be distinguished: $\mathrm{W}-\mathrm{Ti}-\mathrm{As}-\mathrm{Fe} \rightarrow \mathrm{Pb}, \mathrm{Cu}, \mathrm{Zn}$ and outward from the core $\rightarrow \mathrm{Fe}, \mathrm{Au}, \mathrm{Bi}, \mathrm{Ag} \rightarrow(\mathrm{Au}, \mathrm{As}, \mathrm{Sb}) \rightarrow$ $\mathrm{Ca}$. According to this scheme it is possible to relate the genesis of the polymetallic mineralisation in the KZS pluton and its surroundings with the hybrid magmas and with the different distance to the contact with granitoids.

The thermal and mechanical evolution of the continental lithosphere during and after the continental Variscan collision severely constrains the generation and development of different metalogenetic systems including those related to the advance of regional metamorphism, granite magma emplacement and of relatively late hydrothermal processes that involve the circulation and mixture of fluids from distinct sources in a wide range of temperatures (cf. Noronha et al., 2000).

Acknowledgements. The analytical work was supported by the National Committee for Scientific Research, Grant No. N N525 393739 for SM. Dr. U. Kretschmar and S.D. Scott are thanked for providing arsenopyrite standards for our studies. Prof. F. Noronha and two anonymous reviewers are highly appreciated for very valuable comments that improved our paper.

\section{REFERENCES}

Afifi, A.M., Kelly, W.C., Essene, E.J., 1988. Phase relations among tellurides, sulfides, and oxides: I. Thermochemical data and calculated equilibrium. II. Applications to telluride-bearing ore deposits. Economic Geology, 83: 377-404.

Awdankiewicz, M., 2007. Late Palaeozoic lamprophyres and associated mafic subvolcanic rocks of the Sudetes (SW Poland): petrology, geochemistry and petrogenesis. Geologia Sudetica, 39: $11-97$.

Awdankiewicz, M., Kryza, R., Szczepara, N., 2014. Timing of post-collisional volcanism in the eastern part of the Variscan Belt: constraints from SHRIMP zircon dating of Permian rhyolites in the North-Sudetic Basin (SW Poland). Geological Magazine, 151: 611-628.
Bachliński, R., Bagiński, B., 2007. Kłodzko-Złoty Stok granitoid massif. Archiwum Mineralogiae Monograph, 1: 261-273.

Bagiński, B., 2007. P-T-t data on the contact metamorphism of metapelitic rocks induced by Kłodzko-Złoty Stok intrusion (Central Sudetes, Poland). Mineralogia Polonica Special Papers, 30: 20-21.

Bagiński B., Jokubauskas, P., Macdonald, R., Awdankiewicz, M., 2014. Kłodzko-Złoty Stok massif - a new outlook. Mineralogia - Special Papers, 42: 36-37.

Baker, T., Pollard ,P.J., Mustard, R., Mark, G., Graham, J.L., 2005. A comparison of granite-related tin, tungsten, and gold-bismuth deposits, implications for exploration. SGA Newsletter, 61: 5-17. 
Bałdys, L., 1954. Dokumentacja złoża rudy arsenowej i złota w Złotym Stoku (in Polish). Arch. Kopalni.

Batchelor, R.A., Bowden, P., 1985. Petrogenetic interpretation of granitoid rock series using multicationic parameters. Chemical Geology, 48: 43-55.

Białek, D., Werner, T., 2004. Geochemistry and geochronology of the Javornik granodiorite and its geodynamic significance in the Eastern Variscan belt. Geolines, 17: 22-23.

Blevin, P., 2003. Metallogeny of granitic rocks. Geoscience Australia, 14: 1-4.

Blevin, P., Chappell, B.W., 1995. Chemistry, origin and evolution of mineralized granites in the Lachlan Fold Belt, Australia; the metallogeny of I-type and S-type granites. Economic Geology, 90: 1604-1619.

Bouchot, V., Gros, Y., Bonnemaison, M., 1989. Structural controls on the auriferous shear zones of the Saint Yrieix district, Massif Central, France - evidence from the Le Bourneix and Laurieras gold deposits. Economic Geology, 84: 1315-1327.

Bouchot, V., Milesi, J.P., Ledru, P., 2000. Crustal scale hydrothermal Paleofield and related $\mathrm{Au}, \mathrm{Sb}, \mathrm{W}$ orogenic deposits at 310-305 Ma (Massif Central). SGA News Letters, 10: 6-10.

Bouchot, V., Faure, M., Feybesse, J.L., Correira, P., Zacharias, J., 2003. Variscan orogenic gold district related to a regional scale Viséan detachment in the Central Bohemian metallogenic province (Czech Republick): a geodynamic reassessment. In Mineral Exploration and Sustainable Development (eds. D.G. Eliopoulos et al.). Proceedings of the 7th biennial SGA meeting, Athens: 747-750. Millpress, Rotterdam.

Budzyńska, H., 1971. Mineralogy of the arsenic deposit in Złoty Stok (in Polish with English summary). Archiwum Mineralogiczne, 29: 29-88.

Cathelineau, M., Boiron, M. C., Fourcade, S., Marignac, C., 2003. The shift from "mesothermal" to "epithermal" conditions in orogenic gold: definition of a Variscan-type of quartz lode gold deposits. In: Mineral Exploration and Sustainable Development (eds. D.G. Eliopoulos et al.). Proceedings of the 7th biennial SGA meeting, Athens: 751-753. Millpress, Rotterdam.

Chappell, B.W., 2003. Causes of variation in granite suites. Geoscience Australia, 14: 27-34.

Chappell, B.J., White, A.J.R., 1974. Two contrasting granite types. Pacific Geology, 8: 173-174.

Chappel, B.W., White, A.J.R., 2001. Two contrasting granite types: 25 years later. Australian Journal of Earth Sciences, 48: 489-499.

Chopin, F., Schulmann, K., Skrzypek, E., Lehmann, J., Dujardin, J.R., Martelat, J.E., Lexa, O., Corsini, M., Edel, J.B., Štípská P., Pitra, P., 2012. Crustal influx, indentation, ductile thinning and gravity redistribution in a continental wedge: building a Moldanubian mantled gneiss dome with underthrust Saxothuringian material (European Variscan belt). Tectonics, 31: 1-14.

Ciobanu, C.L., Cook, N.J., Damian, F., Damian, G., 2006. Gold scavenged by bismuth melts: an example from Alpine shear-remobilizations in the Highis Massif, Romania. Mineralogy and Petrology, 87: 351-384.

Cockerton, A.B.D., Tomkins, A.G., 2012. Insights into the liquid bismuth collector model through analysis of the Bi-Au Stormont Skarn Prospect, Northwest Tasmania. Economic Geology, 107 667-682.

Cook, N.J., Ciobanu, C., 2004. Bismuth tellurides and sulfosalts from the Larga hydrothermal system, Metaliferi Mts., Romania: paragenesis and genetic significance. Mineralogical Magazine, 68: 301-321.

Cwojdziński, S., 1974. Szczegółowa Mapa Geologiczna Sudetów w skali 1:25 000. Arkusz Złoty Stok. Wyd. Geol. Warszawa.

Cwojdziński, S., 1977. Szczegółowa Mapa Geologiczna Sudetów w skali 1:25 000. Arkusz Trzebieszowice. Wyd. Geol., Warszawa.

Cymerman, Z., 1996. The Złoty Stok-Trzebieszowice regional shear zone: the boundary of terranes in the Góry Złote Mts. (Sudetes). Geological Quarterly, 40 (1): 89-118.
Czesnokow, B.W., 1973. The endogenic zonality of the Beryozovskoye deposit in the Middle Urals. Doklady Academy of Sciences USSR, 210: 915-917.

Dziekoński, T., 1972. Exploitation and ore metallurgy in the Lower Silesia from XIII to XXc (in Polish with English summary). PAN Instytut Historii Kultury Materialnej 4. Ossolineum. Wrocław.

Emerle-Tubielewicz, H., 1979. Szczegółowa Mapa Geologiczna Sudetów w skali 1:25 000. Arkusz Kłodzko. Wyd. Geol., Warszawa.

Franke, W., Żelaźniewicz, A., 2000. The eastern termination of the Variscides: terrane correlation and Modelling in the Variscan belt. Geological Society Special Publications, 179: 63-86.

Frost, C.D., Frost, B.R., 2011. On ferroan (A-type) granitoids: their compositional variability and modes of origin. Journal of Petrology, 52: 39-53.

Gize, A.P., 1999. Organic alteration in hydrothermal sulfide ore deposits. Economic Geology, 94: 967-980.

Goldfarb, R.J., Groves, D.I., Gardoll, S., 2000. Orogenic gold and geologic time: a global synthesis. Ore Geology Reviews, 18:1-75.

Groves, D.I., Goldfarb, R.J., Gebre-Mariam, M., Hagemann, S.G., Robert, F., 1998a. Orogenic gold deposits: a proposed classification in the context of their crustal distribution on relationship to other gold deposit types. Ore Geology Reviews, 13: 7-27.

Groves, D.I., Goldfarb, R.J., Robert, F., Hart, C.J.R., 1998b. Gold deposits in metamorphic belts: overview of current understanding, outstanding problems, future research and exploration significance. Economic Geology, 98: 1-29.

Groves, D.I., Condie, K.C., Goldfarb, R.J., Hronsky, J.M.A., Vielreicher, R.M., 2005. Secular changes in global tectonic processes and their influence on the temporal distribution of gold-bearing mineral deposits. Economic Geology, 100: 203-224.

Haydukiewicz, J., 1973. Upper Devonian Conodonts from Mikołajów slates, Bardo Mts. Sudetes Bulletin de l'Academie Polonaise des Sciences, Série de les Sciences de la Terre, 21: 233-235.

Haydukiewicz, J., 1990. Stratigraphy of Paleozoic rocks of the Góry Bardzkie and some remarks on their sedimentation. Neues Jahrbuch Für Geologie und Paläontologie Abhandlungen,179: 275-284.

Ishihara, S., 1981. The granitoid series and mineralization. Economic Geology 75th Anniversary Volume: 459-484.

Jastrzębski, M., 2009. A Variscan continental collision of the West Sudetes and the Brunovistulian terrane: a contribution from structural and metamorphic record of the Stronie Formation, the Orlica-Śnieżnik Dome, SW Poland. International Journal of Earth Sciences, 98: 1901-1923.

Jensen, E.R., Barton, M.D., 2000. Gold deposits related to alkaline magmatism. SEG Review of Economic Geology, 13: 279-314.

Juskowiak, O., 1959. Some minerals and contact metasomatic phenomena from Podzamek near Kłodzko (in Polish with English summary). Kwartalnik Geologiczny, 3 (2): 235-265.

Kowalski, W.M., 1963. Serpentinization processes in the arsenic ore deposit in Złoty Stok on the Lower Silesia (in Polish with English summary). Prace Geologiczne, 12: 55-76.

Kowalski, W., 1969. Ore minerals from Złoty Stok (Lower Silesia) (in Polish with English summary). Prace Mineralogiczne, 16: 23-40.

Kretschmar, U., Scott, S.D., 1976. Phase relations involving arsenopyrite in the system Fe-As-S and their application. The Canadian Mineralogist, 14: 364-386.

Kwak, T.A.P., 1987. W-Sn Skarn Deposits and Related Metamorphic Skarns and Granitoids. Developments in Economic Geology, 24.

Lang, J.R., Baker, T., 2000. Intrusion-related gold systems: the present level of understanding. Mineralium Deposita, 36: 477-489.

Lang, J.R., Baker, T., Hart, C., Mortensen, J.K., 2000. An exploration model for intrusion-related gold systems. SGA Newsletter, 40: 6-14. 
Lehmann, B., 1994. Granite-related rare-metal mineralization: a general geochemical framework. In: Metallogeny of Collisional Orogens Focused on the Erzgebirge and Comparable Metallogenic Settings: Proceedings of the IAGOD Erzgebirge Meeting Geyer, Germany (eds. R. Seltmann, H. Kampf and P. Möller): 342-349. Czech Geol. Survey, Prague.

Lis, J., Sylwestrzak, H., 1986. Minerały Dolnego Śląska (in Polish). Wyd. Geol., Warszawa.

Lorenc, M., 1994. Role of magmas in the granitoid evolution (a comparative study of some Hercynian massifs) (in Polish with English summary). Geologia Sudetica, 28: 1-130.

Maniar, P.D., Piccoli, P.M., 1989. Tectonic discrimination of granitoids. GSA Bulletin, 101: 635-643.

Marheine, D., Kachlik, V., Maluski, H., Patocka, F., Żelaźniewicz, A., 2002. The Ar-Ar ages from the West Sudetes (NE Bohemian Massif): constrains on the Variscan polyphase tectonotherma development. Geological Society Special Publications, 201 133-155.

Matte, P.H., Maluski, H., Rajlich, P., Franke, W., 1990. Terrane boundaries in the Bohemian Massif: result of large-scale Variscan shearing. Tectonophysics, 177: 151-170.

Mazur, S., Aleksandrowski, P., Kryza, R., Oberc-Dziedzic, T., 2006. The Variscan Orogen in Poland. Geological Quarterly, $\mathbf{5 0}$ (1): 89-118.

Mazur, S., Aleksandrowski, P., Turniak, K., Awdankiewicz, M. 2007. Geology, tectonic evolution and Late Paleozoic magmatism of Sudetes - an overview. Archivum Mineralogiae Monograph, 1: 59-87.

Mazur, S., Turniak, K., Szczepański, J., McNaughton, N.J., 2015 Vestiges of Saxothuringian crust in the Central Sudetes, Bohemian Massif: Zircon evidence of a recycled subducted slab provenance. Gondwana Research, 27: 825-839.

Mikulski, S.Z., 1996a. Gold mineralization within contact-metamorphic and shear zones in the Golden Creek quarry - the Zloty Stok Au-As deposit area (Sudetes). Geological Quarterly, 40 (3): 407-442.

Mikulski, S.Z., 1996b. Gold mineralization in the Złoty Jar quarry near the Złoty Stok As-Au deposit (Sudetes, SW Poland) (in Polish with English summary). Przegląd Geologiczny, 44 1205-1210.

Mikulski, S.Z., 1998. Gold-bearing ore mineralization from Bardo Śląskie (Central Sudetes) (in Polish with English summary). Przegląd Geologiczny, 46: 1261-1267.

Mikulski, S.Z., 1999a. Scheelite and gold-bearing mineralization in the Ptasznik roof pendant, Sudetes, Poland. In: Mineral Deposits: Processes to Processing: Proceedings of the 5th SGA meeting and 10th Quadrennial IAGOD meeting, London UKC (eds. J. Stanley et al.,): 393-396. A.A. Balkema, Rotterdam/Brookfield.

Mikulski, S.Z., 1999b. Berezyty z Dębowinki - nowy typ genetyczny złotonośnej mineralizacji w Sudetach. In: Wybrane problem stratygrafii, tektoniki i mineralizacji kruszcowej na Dolnym Śląsku (in Polish) (ed. A. Muszer): 54-59. Wydawnictwa Uniwersytetu Wrocławskiego.

Mikulski, S.Z., 2000. Prospecting of scheelite and gold mineralization in the Ptasznik roof pendant of the Kłodzko Złoty Stok intrusion in the Sudetes Mts. (in Polish with English summary) Biuletyn Państwowego Instytutu Geologicznego, 391: 5-88.

Mikulski, S.Z., 2001. Late-Variscan gold-bearing arsenic-polymetallic mineralization within Saxothuringian zone in the Polish Sudetes, Northeast Bohemian Massif. In: Mineral Deposits at the Beginning of the 21st Century: Proceedings of the Joint $6^{\text {th }}$ SGA-SEG Meeting, Kraków, Poland (eds. A. Piestrzyński et al.):787-790. A.A. Balkema Publishers, Lisse.

Mikulski, S.Z., 2005a. Geological, mineralogical and geochemical characteristics of the Radzimowice Au-As-Cu deposit from the Kaczawa Mountains (Western Sudetes, Poland) - an example of the transition of porphyry and epithermal style. Mineralium Deposita, 39: 904-920.

Mikulski, S.Z., 2005b. The telluride mineralization event(s) within the Late-Variscan gold deposits in the Western Sudetes (NE part of the Bohemian Massif, SW Poland). In: Mineral Deposit Research: Meeting the Global Challenge: Proceedings of the
Eight Biennial SGA Meeting, Beijing, China (eds. J.W. Mao and F.P. Bierlein): 1415-1418. Springer, Berlin.

Mikulski, S.Z., 2007a. The late Variscan gold mineralization in the Kaczawa Mountains, Western Sudetes. Polish Geological Institute Special Papers, 22: 1-162.

Mikulski, S.Z., 2007b. Comparison of geotectonic settings and age of gold formations in the Kaczawa Mountains (SW Poland) with those from European Variscan belt during Carboniferous-Permian. In: Digging Deeper: Proceedings of the Ninth Biennial SGA Meeting, Dublin, Ireland (ed. C.J. Andrews): 601-604.

Mikulski, S.Z., 2010. The characteristic and genesis of the gold-bearing arsenic polymetallic mineralization in the Czarnów deposit (Western Sudetes) (in Polish with English summary). Biuletyn Państwowego Instytutu Geologicznego, 429: 303-320.

Mikulski, S.Z., 2011. Gold mineralization of the Kłodzko-Złoty Stok intrusion contact zone, Sudetes, SW Poland. Archivum Mineralogiae Monograph, 2: 27-43.

Mikulski, S.Z., 2015. The prospective maps of metal ores in Poland at scale 1:200 000 - gold vein and metasomatic ores associated with sulfide mineralization in the Lower Silesia, Upper Silesia and Małopolska (S Poland) (in Polish with English summary). Przegląd Geologiczny, 63: 546-555

Mikulski, S.Z., Kozłowski A., 2001. The origin conditions of primary and detrital scheelite related to the Variscan granites in the Central Sudetes (SW Poland). In: Mineral Deposits at the Beginning of the 21st Century: Proceedings of the Joint 6th SGA-SEG Meeting, Kraków, Poland (eds. A. Piestrzyński et al.): 453-456. A.A. Balkema Publishers, Lisse.

Mikulski, S.Z., Kozłowski A., 2011. Fluid inclusion studies in quartz from gold-bearing sulphide deposits in Sudetes. Gold in Poland, Archivum Mineralogiae Monograph, 2: 99-117.

Mikulski, S.Z., Speczik, S., 2008. Organic and inorganic geochemistry of gold mineralization at the Zloty Stok, SW Poland. Applied Earth Science (Transactions of Institution of Minining and Metallurgy - B), 117: 149-159.

Mikulski, S.Z., Speczik, S., 2009. The unstructured organic matter and its relation to serpentinization and gold mineralization in the Zloty Stok Au-As Skarn Deposit (SW Poland). In: Smart Science for Exploration and Mining: Proceedings of the 10th Biennial SGA Meeting, Townsville, Australia (eds. P.J. Williams et al.): 248-250.

Mikulski, S.Z., Wierchowiec, J., 2013. Placer scheelite and gold from alluvial sediments as indicators of the primary mineralization - examples from the Sudetes and Fore-Sudetic Block (Lower Silesia region, SW Poland). Geological Quarterly, 57 (3): 503-514.

Mikulski, S.Z., Williams, I.S., 2014a. Zircon U-Pb ages of granitoid apophyses in the western part of the Kłodzko-Złoty Stok Granite Pluton (SW Poland). Geological Quarterly, 58 (2): 251-262.

Mikulski, S.Z., Williams, I.S., 2014b. Zircon U-Pb dating of igneous rocks from the Radzimowice and Wielisław Złotoryjski auriferous polymetallic deposits, Sudetes, SW Poland. Annales Societatis Geologorum Poloniae, 84: 213-233.

Mikulski, S.Z., Williams, I.S., Baginski, B., 2013. Early Carboniferous (Viséan) emplacements of the collisional the Kłodzko-Złoty Stok granitoids (Sudetes, SW Poland): constrains from geochemical and $\mathrm{U}-\mathrm{Pb}$ zircon age data. International Journal of Earth Sciences, 102: 1007-1027.

Mochnacka, K., 2000. Regularities of ore mineralization development within metamorphic cover of the Karkonosze Mts. - an attempt of connection with geotectonic environment (in Polish with English summary). Prace Specjalne Polskie Towarzystwo Mineralogiczne, 16: 223-258.

Morávek, P., Pertold, Z., Punčochář, M., Studničná, B. Zachariáš, J., Moravek, P., eds.,1996. Gold deposits in Bohemia. Czech Geol. Survey, Prague.

Möller, P., Kersten, G., 1994. Electrochemical accumulation of visible gold on pyrite and arsenopyrite surfaces. Mineralium Deposita, 29: 404-413.

Müller, D., Groves, D.I., 2000. Potassic Igneous Rocks and Associated Gold-Copper Mineralization. 3rd ed. Springer, Berlin, Heidelberg, New York. 
Muszer, A., 1992. Native gold from Złoty Stok (Lower Silesia) (in Polish with English summary). Archiwum Mineralogiczne, 48: 81-99.

Muszer, A., 1997. Characteristic of the ore mineralization in the northern and central parts of the Złote Mountains on the geological background (in Polish with English summary). Acta Universitatis Wratislaviensis, Prace Geologiczno-Mineralogiczne, 52: 1-130.

Muszer, A., 2011. Gold at Złoty Stok - history, exploitation, characteristic and perspectives. Archivum Mineralogiae Monograph, 2: $45-62$.

Nejbert, K., Siuda, R., Borzęcki, R., Matyszczak, W., 2013. Mineralogy of antimony ores mined at Debowinka in the Bardzkie Mts (Sudetes) SW Poland. Mineralogia Special Papers, 41: 68.

Neuhaus, A., 1933. Die Arsen-Golderzlagerstätte von Reichenstein in Schlesien (in German). Archiv für Lagerstättenforschung, $\mathbf{5 6}$ $1-91$.

Niczyporuk, K., Speczik, S., 1993. Gold in arsenic minerals of Złoty Stok. Mineralogia Polonica, 24: 21-32.

Noronha, F., Cathelineau, M., Boiron, M., Banks, M.C., Doira, A., Ribeiro, M.A., Norgueira, P., Guedes, A., 2000. A three stage fluid flow model for Variscan gold metallogenesis in northern Portugal. Journal of Geochemical Exploration, 71: 209-224.

Oberc, J. 1972. Budowa geologiczna Polski, t. IV, Tektonika cz. 2 Sudety i obszary przyległe. Wyd. Geol., Warszawa.

Oberc, J., Badura, J., Przybylski, B., Jamrozik, L., 1994 Szczegółowa Mapa Geologiczna Sudetów w skali 1:25 000, arkusz Bardo Śląskie. Wyd. Geol., Warszawa.

Oberc-Dziedzic, T., Kryza, R., Pin, C., Madej, S., 2015. Variscan granitoid plutonism in the Strzelin Massif (SW Poland): petrology and age of the composite Strzelin granite intrusion. Geological Quarterly, 57 (2): 269-288.

Olszyński, W., Speczik, S., 1993. Ore mineralization of Lutynia (SW Poland). Geological Quarterly, 37 (4): 485-500.

Petrascheck, W.E., 1933. Die Erzlagerstätten des Schlesischen Gebirges (in German). Archiv für Lagerstättenforschung, 59: 1-53.

Roedder, E., 1984. Fluid inclusions. Reviews in Mineralogy, 12.

Richards, J.P., 1995. Alkalic-type epithermal gold deposits - a review. Mineralogical Association of Canada Short Course Series, 23: $367-400$.

Sawicki, L., 1980. Mapa Geologiczna Polski. B - Mapa bez utworów czwartorzędowych w skali 1:200 000. Wyd. Geol., Warszawa.

Schulmann, K., Gayer, R., 2000. A model for a continental accretionary wedge developed by oblique collision: the NE Bohemian massif. Journal of the Geological Society, 157: 401-416.

Sharp, Z.D., Essene, E.J., Kelly, W.C., 1985. A re-examination of the arsenopyrite geothermometer: pressure considerations and applications to natural assemblages. The Canadian Mineralogist, 23: 517-534.

Sillitoe, R.H., 1991. Intrusion-related gold deposits. In: Gold metallogeny and exploration (ed. R.P. Foster): 165-209. Blackie, Glasgow.

Sillitoe, R.H., 2000. Gold-rich porphyry deposits: desrcriptive and genetic models and their role in exploration and discovery. Economic Geology, 13: 315-345.
Sillitoe, R.H., Thompson, J.F.H., 1998. Intrusion-related vein gold deposits: Types, tectono-magmatic settings and difficulties of distinction from orogenic gold deposits. Resource Geology, 48: 237-250.

Smulikowski, K., 1979. Polymetamorphic evolution of the crystalline complex of Śnieżnik and Góry Złote Mts in the Sudetes (in Polish with English summary). Geologia Sudetica, 14: 7-76.

Speczik, S., 1994. Metasomatic processes in the vicinity of the Kłodzko-Złoty Stok massif. In: Second Workshop on Variscan Metallogeny (ed. S. Speczik): 85-101. Kraków, Wrocław, Warszawa.

Spiridionov, E.M., 1996. Granitic rocks and gold mineralization of North Kazakhstan. In: Granite-related ore deposits of Central Kazakhstan and adjacent areas (eds. V. Shatov ,R. Seltmann, A. Kremenetsky, B. Lehmann, V. Popov and P. Ermolov): 197-217. Glagol Publishing House, St. Petersburg.

Thompson, J.F.H., Newberry, R.J., 2000. Gold deposits related to reduced granitic intrusions. SEG Reviews in Economic Geology, 13: $377-400$.

Thompson, J.F.H., Sillitoe, R.H., Baker, T., Lang, J.R., Mortensen, J.K., 1999. Intrusion-related gold deposits associated with tungsten-tin provinces. Mineralium Deposita, 34: 323-334.

Wajsprych, B., 1978. Allochthonous Paleozoic rocks in the Visean of the Bardzkie Mts., Sudetes (in Polish with English summary). Annales Societatis Geologorum Poloniae, 58: 99-127.

Wajsprych, B., 1986. Sedimentary record of tectonic activity on a Devonian-Carboniferous continental margin, Sudetes. In: IAS 7th Regional Meeting, Excursion Guidebook (ed. A.K. Teisseyre): 141-164. Ossolineum, Kraków, Wrocław.

Wiencke, O., 1907. Über die Arsenerzlagerstätten von Reichenstein (in German). Zeitschrift für praktische Geologie, 15: 273-285.

Wierzchołowski, B., 1976. Granitoids of the Kłodzko-Złoty Stok massif and their contact influence on the country rocks (petrographic characteristics) (in Polish with English summary). Geologia Sudetica, 11: 3-147.

Wierzchołowski, B., 1977. Dike rocks of the Kłodzko-Złoty Stok granitoid massif. Geologia Sudetica, 12: 7-28.

Winkler, H.G.F., 1967. Petrogenesis of Metamorphic Rocks. Springer-Verlag, New York.

Wojciechowska, I., 1975. Tectonics of the Kłodzko-Złoty Stok granitoid massif and its country rocks in the light of the mesostructural investigation (in Polish with English summary). Geologia Sudetica, 10: 61-121.

Zachariáš, J., Pertorld, Z., Pudilová, M., Žák, K., Pertoldová, J., Stein, H., Markey, R., 2001. Geology and genesis of Variscan porphyry-style gold mineralization, Petráčkova hora deposit, Bohemian Massif, Czech Republic. Mineralium Deposita, 36: 517-541.

Zachariáš, J., Žak, K., Pudilová, M., Snee, L.W., 2013. Multiple fluid sources/pathways and severe thermal gradients during formation of the Jilové orogenic gold deposit, Bohemian Massif, Czech Republic. Ore Geology Reviews, 54: 81-109.

Zachariáš, J., Morávek, P., Gadas, P., Pertoldová, J., 2014. The Mokrsko-West gold deposit, Bohemian Massif, Czech Republick: mineralogy, deposit setting and classification. Ore Geology Reviews, 58: 238-263. 